\title{
Stem access in regular and irregular inflection: Evidence from German participles is
}

\author{
Eva Smolka $^{\mathrm{a}, *}$, Pienie Zwitserlood ${ }^{\mathrm{b}}$, Frank Rösler ${ }^{\mathrm{a}}$ \\ ${ }^{a}$ Experimental and Biological Psychology, Philipps-University, Marburg, Germany \\ b Psychological Institute II, Westfälische Wilhelms-University, Münster, Germany
}

\begin{abstract}
This study investigated whether German participles are retrieved as whole words from lexical storage or whether they are accessed via their morphemic constituents. German participle formation is of particular interest, since it is concatenative for both regular and irregular verbs and results from combinations of regular/irregular stems with regular/irregular suffixes. Data from visual priming showed that regular and irregular participles facilitated their base verbs to the same degree, which argues against different processing systems. Furthermore, "illegal combinations" of participle affixes and verbal or nonverbal stems (geworft, gewurft) were as effective as correct participles (geworfen) in facilitating the morphologically related base verb (werfen). This indicates that stems contained in illegal combinations were accessed, regardless of whether they originated from regular or irregular verbs. These findings strongly argue for a single system that processes both regular and irregular inflection via access to morphemic constituents. Such a single processing model is suggested.
\end{abstract}

Keywords: Inflectional morphology; Regularity; Participle priming; Illegal combinations; Morphological decomposition; Lexical retrieval; Single system; Stem access

\section{Introduction}

The organization and information types of the mental lexicon remain an unsettled issue in psycholinguistic

\footnotetext{
This study was supported by the German Research Foundation (DFG), Grant 254/2 to Frank Rösler. We thank Lena Squarra and Judith Halle for running the experiment, and Juan A. Hernández for his statistical advice. We would further like to thank Mihal Raveh and two anonymous reviewers for helpful comments on an earlier version of this article.

* Corresponding author. Present address: Departmento de Psicología Cognitiva, Universidad de La Laguna, 38205 La Laguna, Tenerife, Spain.

E-mail address: esmolka@ull.es (E. Smolka).
}

research. Much debated questions are (a) whether morphologically complex words are processed via parsing or via retrieval from memory, and (b) whether these processes are handled by a single or by a dual system.

These are two separate questions that are often confounded and models seldom take an explicit stance. We attempt to evaluate existing models with respect to their position on these issues. Connectionist network models assume a single associative memory system that directly computes meaning representations from orthographic representations. Morphological regularities are an epiphenomenon of form-to-meaning mappings in such models (Plaut \& Gonnerman, 2000; Rueckl, Mikolinski, Raveh, Miner, \& Mars, 1997; Smith, 1995). Thus, there is one single system and a single process that handles all 
types of words. This is in contrast to other single system models, where different processes operate consecutively. For example, morpheme-first hypotheses assume that all complex forms are parsed into separate stem and affix units before whole-word representations can be accessed (Taft, 1979, 2004; Taft \& Forster, 1975). The reverse sequence is assumed by word-first models. Complex forms are retrieved as whole-word units before their morphemic constituents can be accessed (Giraudo \& Grainger, 2000, 2001), which, according to some models occurs only rarely as a fall-back procedure (Butterworth, 1983).

Mixed approaches have both processes - parsing and access to full forms - run in parallel. Parsing can only be applied to complex words that are formed by productive processes, while words with nonproductive patterns are stored in the lexicon alongside with information about their morphological make-up (Chialant \& Caramazza, 1995; Clahsen, 1999; Frost, Forster, \& Deutsch, 1997; Marslen-Wilson, Tyler, Waksler, \& Older, 1994; Pinker, 1998; Schreuder \& Baayen, 1995). However, these models differ in their definitions of 'productive' forms that undergo parsing, and consequently also in the definitions of those words that are to be retrieved from memory as 'unproductive' forms. Most important, the models differ on the assumption whether parsing and retrieval are incorporated in a single system (Frost et al., 1997; Schreuder \& Baayen, 1995), or whether the processes are assumed to run in two completely distinct systems (Clahsen, 1999; Pinker, 1998; Prasada \& Pinker, 1993).

Past tense and participle formation in several languages has often been used to investigate potential differences between productive and unproductive forms. Differences between productive, that is, regular inflection and unproductive, that is, irregular inflection were taken as support for two different systems. At the root of the dual-system hypothesis for regular and irregular inflection are data from a seminal study of Stanners, Neiser, Hernon, and Hall (1979). Regular past tense forms (poured) primed their base-form targets (pour) just as effectively as primes that were identical to the target. Base forms of irregular verbs (hang) were also primed when preceded by their past tense primes (hung), but to a lesser extent than by identical primes. Stanners et al. (1979) inferred two different systems and coined the concepts of "full" and "partial" activation that a base form may receive within such systems. In one system, only the base form has a lexical entry, which is shared by all other regularly inflected forms. Regular inflections are decomposed into base and affixes prior to lexical access, and only the base form is accessed. This access to the same entry produces the "full" activation of a base form. A second system stores all variants of irregularly inflected forms, as well as its base form, tightly connected to each other. This yields the "partial" activation of base forms when the irregular past tense form is accessed. These findings, together with the linguistically motivated distinction between a universal default and a lexical storage system (Chomsky \& Halle, 1968) lay the cornerstone for the so-called "dual mechanism" account for inflectional systems (e.g., Clahsen, 1999; Clahsen, Eisenbeiss, Hadler, \& Sonnenstuhl, 2001; Clahsen, Eisenbeiss, \& Sonnenstuhl-Henning, 1997; Pinker, 1998, 1999; Pinker \& Ullman, 2002; Prasada \& Pinker, 1993; Ullman, 2001). The model assumes two innate but completely separate systems: a parsing system that applies default rules to base forms, and a lexical storage system that stores all exceptions to these default rules as whole words.

Subsequent studies corroborated processing differences between regular and irregular verbs: In English, full priming was found for regular verbs, and either partial priming (Napps, 1989) or no priming at all for irregular verbs (Marslen-Wilson, 1999). A similar difference was reported for German participles (Sonnenstuhl, Eisenbeiss, \& Clahsen, 1999). The picture became somewhat clouded when full priming was also found for irregular verbs in English (Forster, Davis, Schoknecht, \& Carter, 1987), and when recent priming studies in Italian (Orsolini \& Marslen-Wilson, 1997) and French (Meunier \& Marslen-Wilson, 2004) revealed similar past tense or participle priming effects for regular and irregular verbs. Such findings do not fit with a strict distinction between decomposition of regular forms and full lexical storage of irregular forms. Moreover, in a study on German participles (Smolka, Rösler, \& Wiese, 2003), subgroups of irregular verbs showed rather heterogeneous priming patterns and differences in priming patterns between regular, semi-regular and irregular verbs seemed more determined by the verbs' frequency of occurrence than by their group membership: In the high-frequency range, the priming patterns of semi-regular verbs were similar to those of irregular verbs, whereas in the low-frequency range, semi-regular verbs showed priming patterns similar to those of regular verbs. Furthermore, these priming patterns mainly depended on factors other than regularity, such as the inflection type of the target, the frequency, morphological relation and the meaning relation of prime and target.

Thus, the evidence from priming studies supporting separate systems for regular and irregular forms can be considered inconclusive at best. This study provides an attempt to reveal the system that may explain the processing of regular and irregular inflection. The first aim was to test the issue of single versus dual systems. For this purpose, we examined regular and irregular participle priming with rigorous control over confounding variables. The second aim of this study was a search for the access codes of regular and irregular inflection. So far, this is the first study that uses nonword priming 
to examine whether regular and irregular inflection is parsed or retrieved as whole words. These issues will be spelled out below, citing evidence and models where relevant. To facilitate this, some information about German past participles is provided next.

\section{German participle formation}

German participle formation provides a means to tease apart factors which are confounded in many languages, such as suffixation, stem preservation, and predictability. The affixation of German participles is completely predictable. While the suffixation in English is largely restricted to regular verbs (see Marcus, Brinkmann, Clahsen, Wiese, \& Pinker, 1995, Table 3), the affixation in German is the same for regular and irregular participle formation: the prefix ge- and one of two suffixes, $-t$ or $-e n$, are attached to a stem. The prefix $g e$ - is used for both regular and irregular participle formations. Its distribution is, without exception, prosodically conditioned (Wiese, 1996b), which is the reason why it is not focused upon here. ${ }^{1}$

It is a particular stem-affix combination that renders a participle either regular or irregular. As Table 1 shows, both stem and suffix come in a 'regular' and an 'irregular' shape. The 'regular' stem preserves the infinitive stem, as in ge-kauf-t (bought) or ge-lauf-en (run). Any vowel change in the stem, as in ge-soff-en (boozed) from sauf-en (booze), which is sometimes accompanied by a consonant change, creates an irregular participle (for a description of these vowel changes see Wiese, 1996a). With regard to suffixation, the $-t$ suffix is considered the 'regular' suffix, whereas the -en suffix is considered the 'irregular' one. Since both suffix types combine with regular and irregular stems, this leads to different irregular forms, which we arbitrarily label 'irregular 1', 'irregular 2', or 'irregular 3' verbs (see Table 1). 'Irregular 1' participles combine the infinitive stem with the -en suffix, 'irregular 2' participles have a vowel change in the stem and the -en suffix, and 'irregular 3' participles a vowel change and the $-t$ suffix. 'Regular' participles combine the infinitive stem with the $-t$ suffix. "Dual mechanism" accounts (Clahsen, 1999; Marcus et al., 1995; Sonnenstuhl et al., 1999) consider this type as the default, since this formation is productive and applied in 'elsewhere' conditions: New verbs like simsen (send an SMS), denominal verbs like filmen (film, v.) from Film (film, n.), and derived verbs like rebellieren (rebel, v.) from Rebell (rebel, n.) are formed productively in this group. Moreover, low-frequency irregular verbs are regularized into this class.

\footnotetext{
${ }^{1}$ If the first syllable of a stem carries the main stress, the prefix ge-must occur, otherwise it must not (Wiese, 1996b).
}

The application of the 'regular' participle formation in elsewhere conditions is mirrored in their high type frequency. This is actually similar to English, where regular verbs are of high type frequency and irregular verbs are of high token frequency. ${ }^{2}$ Table 1 summarizes the distribution of the roughly 1900 monomorphemic German verbs that are included in the CELEX data base (Baayen, Piepenbrock, \& Van Rijn, 1993). Of these, about 200 types are irregular verbs, and about 1700 are 'regular' verbs of present-day German. Thus, even though all possible stem and suffix combinations are found in German, their type and token frequencies are extremely skewed.

A further important characteristic of German participle formation is that the inflection type cannot be predicted from the surface form of a verb. Whereas the theme vowel in an Italian infinitive (e.g., Caramazza, Laudanna, \& Romani, 1988; Orsolini \& Marslen-Wilson, 1997), or the citation form of a Hebrew verb (e.g., Deutsch, Frost, \& Forster, 1998) denote the conjugation class to which a verb belongs, the surface form of a German verb allows no (synchronical) prediction as to whether a verb is inflected in a regular or irregular way. Several attempts have been made to search for onset and rhyme sequences that coincide with regular or irregular stem alternation (Beedham, 1994). For example, most verbs with the onset /va/, like wachen, wallen, and warnen are regular, and verbs with the rhyme /Ink/ in the stem, such as trinken, sinken, and stinken, tend to be irregular. However, the exceptions to such phonological rules are too many, as the irregular verbs wachsen and waschen or the regular verbs winken and blinken demonstrate. Thus, the assignment of German verbs to inflectional classes cannot be associated with any phonological features of the verbs involved. On the contrary, Durrell (2001) argues that it would be very surprising if this were possible, since throughout the history of Germanic many regular verbs like setzen (set) have been derived from irregular verbs with almost identical phonological structure like sitzen (sit). Furthermore, between Middle High German and Modern German, over two hundred irregular verbs became regular without it being possible to identify any phonological motivation behind these changes. Table 1 illustrates that verbs with similar rhymes like kaufen (buy), laufen (run), and saufen (booze) belong to different inflectional classes.

To summarize, the concatenation of the German participle formation is completely predictable: $g e$ - is prefixed to a stem, followed by one of two suffixes (- $t$ or

\footnotetext{
${ }^{2}$ Clahsen (1999) and Marcus et al. (1995) argued that this was not the case for German participles, however, they counted prefixed variants of a verb as separate types, thus increasing the number of irregular verb types.
} 
Table 1

German participle formation according to stem and suffix combinations

\begin{tabular}{|c|c|c|c|c|c|}
\hline Verb class & Citation form & Participle & Stem & Suffix & $N$ \\
\hline 'Regular' & kaufen (buy) & gekauft & Infinitive & $-t$ & 1700 \\
\hline 'Irregular 1' & laufen (run) & gelaufen & Infinitive & -en & 41 \\
\hline 'Irregular 2' & saufen (booze) & gesoffen & Vowel change & -en & 144 \\
\hline 'Irregular 3' & brennen (burn) & gebrannt & Vowel change & $-t$ & 15 \\
\hline
\end{tabular}

Note. Verb class gives the terms used in the present study. In traditional German grammars, 'regular' verbs are called "weak" verbs, 'irregular 1' and 'irregular 2' verbs are subsumed under "strong verbs", and 'irregular 3' verbs are referred to as "mixed verbs". All examples are given in their orthographic form, hence -en suffix, and not in their phonetic form, where the letter $e$ is realized as schwa /ə/ or is not realized at all. $N$, type count of monomorphemic verbs, taken from CELEX (Baayen et al., 1993).

-en). However, whether a stem undergoes vowel alternation or not, and which of the suffixes is attached, is completely unpredictable from the surface form of a verb.

\section{Regular versus irregular participles: one or two systems?}

The first major aim of our study is to test whether one or two systems are required for the processing of regular and irregular inflection. Strong support for claiming a dual system was derived from a priming study on German participles by Sonnenstuhl et al. (1999). These authors measured the amount of facilitation that 'regular' and 'irregular 1' participles exerted to the recognition of a related verb target. Inflected verb targets such as kaufe (buy, 1st person singular present) were facilitated to the same degree by their 'regular' participle gekauft $(30 \mathrm{~ms})$ as by the identical prime kaufe $(30 \mathrm{~ms})$. This "full" participle priming was taken as evidence that regularly inflected forms are parsed and activated via the base kauf. In contrast, 'irregular 1' participles such as gelaufen (ran) primed their verb target laufe (run, 1st person singular present) to a lesser degree $(25 \mathrm{~ms})$ than identity primes $(57 \mathrm{~ms})$. This was interpreted as evidence that irregular participles are not parsed but rather stored as whole units in lexical memory, where they activate morphologically-related verb forms by means of network associations.

The question is, whether this interpretation is warranted. First, previous studies in English used bare stems in the identity condition to measure stem priming. In contrast, Sonnenstuhl et al. (1999) used an inflected verb form, namely the inflection of the first person singular present (infinitive stem $+-e$ suffix), so that their identity priming does not represent "stem priming" per se. On the contrary, an inflection in the identity condition does not provide a valid measure of stem access unless one presupposes that both regularly and irregularly inflected verb forms are decomposed into stem and affixes. An identity condition that does not represent stem priming weakens the concept of "full priming" (as indication of decomposition via stem access) relative to that of "partial priming" (as indication of whole word access via semantic priming), and thus also any conclusions regarding decomposition or whole word access. In our study, we addressed the question whether participles are decomposed or stored as whole words by means of nonword priming, as we describe further below.

A second concern regards the critical interaction between verb class and priming in the study of Sonnenstuhl et al. (1999). This interaction results from a difference in identity priming between regular $(30 \mathrm{~ms})$ and irregular $(57 \mathrm{~ms})$ verbs rather than from a difference between the participle priming of regular $(30 \mathrm{~ms})$ and irregular ( $25 \mathrm{~ms}$ ) verbs (see also commentary of Drews, 1999). Appendix A provides the distributional variables of the verb stimuli used in that experiment. As Appendix A indicates, the surface forms (1st person singular present) of the irregular verbs in the identity condition were of statistically significantly higher frequency than those of the regular verbs. ${ }^{3}$ Hence, faster responses for the irregular identity condition than for the regular identity condition may have been the result of frequency effects. Moreover, given the skewed frequency distribution of regular and irregular verbs in general, it is quite difficult to closely match regular and irregular participles on frequency. Indeed, regular participles in Sonnenstuhl et al. were of lower surface and lemma frequency than irregular participles (see Appendix A). Therefore, unless the possibility is ruled out that frequency was a major cause of those results, the interaction-different relations of participle and identity priming for regular and irregular verbs - does not allow an unequivocal interpretation with regard to whether participles are decomposed or stored as whole words.

We controlled for such confounding variables in the present study. Each participle was paired with a control participle, carefully matching on both surface and

\footnotetext{
${ }^{3}$ A paired $t$-test confirmed on the items used in Sonnenstuhl et al. (1999) that the mean surface frequency of identical 'irregular 1' primes and targets (9.62/one million) was significantly higher than that of identical 'regular' primes and targets (3.76/one million; $p<.05$ ).
} 
lemma frequency, as well as for number of letters and neighbors. ${ }^{4}$ Furthermore, in Sonnenstuhl et al. (1999), the participle condition kept the meaning of the stem constant and varied the morphological form between prime and target (ge-kauf-t-kauf-e), whereas the unrelated condition kept the morphological form constant and varied the meaning of the stems (hüpf-e-kauf-e). The actual measurement of participle priming relative to the unrelated baseline thus comprised a comparison of both meaning and form. Importantly, in our study, test and control participles had the same affixes (prefix ge- and suffix $-t$ or $-e n$ ), providing maximal form control. Because of these rigorous controls, any priming can be attributed to the morphological (and semantic) relatedness of participle and target, and any difference between regular and irregular participle priming can be attributed to a difference between the two verb classes. Differences in participle priming would thus indicate a dual system, whereas equivalent participle priming would denote a single system.

\section{Illegal combination participles: decomposition or whole- word access?}

Our second aim was to investigate whether participles are parsed into constituent morphemes or retrieved as whole-word units. The above comparison of regular and irregular participle priming may reveal whether a single or a dual system is required to explain the processing of regular and irregular inflection. However, both regular and irregular participle priming could reflect morphological as well as semantic priming. Hence, a different measure is required to uncover the size of the access units. Illegal combinations of morphemic constituents have been used for this purpose. Since illegal combinations do not exist and cannot be retrieved from memory, they can only facilitate a morphologically related target if their morphemic constituents are accessed.

Available data on illegal combinations do not provide a unitary picture. For example, Frost et al. (1997) combined existing roots with existing word patterns of Hebrew to form illegal combinations. These did not prime target words with the same root, although the root letters by themselves yielded priming. Frost et al. (1997) concluded that root morphemes can induce facilitation only if they are lexically presented as abstract

\footnotetext{
${ }^{4}$ Neighborhood size reflects the number of words that differ by one letter with respect to a target (word or nonword) while preserving the identity and position of the other letters (e.g., Arduino \& Burani, 2004). For example, the participle gekauft has a neighborhood size of two, due to its two neighbours gerauft and getauft. The pseudostem participle gekaust has seven word neighbors, namely gekauft, gehaust, gejaust, gelaust, gepaust, gesaust, and gezaust.
}

root morphemes, but not if they are embedded in nonwords. Similarly, Drews and Zwitserlood (1995) found no facilitation for target words preceded by illegal combinations of a target's root and a derivational suffix. This contrasts with a recent study in French, in which Longtin and Meunier (2005) manipulated the root-suffix combinability to construct illegal combinations. Depending on suffix type, their combinations were either formed by productive rules which resulted in nonexistent but 'interpretable' nonwords, or they resulted in ungrammatical and thus 'noninterpretable' nonwords. Both types produced the same amount of priming as did existing derived words, providing strong evidence for morphological decomposition in visual word recognition.

In our study, verb targets like zähmen (to tame), were either preceded by an illegal combination participle, such as gezahmt, or by a closely matched pseudostem participle, such as gezähst. Illegal combination and pseudostem participles both represented nonwords that contained the typical participle affixes: the ge- prefix and either the regular - $t$ or the irregular -en suffix. Pseudostem participles comprised a form-related but nonexistent stem like zähs, whereas illegal combination participles contained an existing stem that was morphologically related to the verb target like zahm (tame, adj.). Priming of the target zähmen will be observed only if the meaning of the stem zahm is accessed.

Two different types of stem were used for the construction of illegal combinations: Stems from within the verb paradigm, and stems from outside the verb paradigm. For half of the irregular verbs, we constructed illegal combinations by combining the correct participle stem with an incorrect suffix. For example, the stem of the irregular verb werfen (throw) undergoes vowel change ('ablaut') and is combined with the -en suffix to provide the participle geworfen (thrown). We combined this correct participle stem with the incorrect participle suffix $-t$ to produce an illegal combination like geworft.

For a small set of irregular verbs, a stem that does not occur in the verbal paradigm can be found. For example, the noun stem $\operatorname{Wurf}$ (throw, n.) is morphologically related but contains an 'ablaut' that differs from all verbal stems of the 'irregular 2' verb werfen (throw): werf (infinitive), worf (participle), warf (preterit), wirf (2nd and 3rd person singular present), and würf (conditional). We used such nonverbal stems to construct illegal combinations such as gewurft.

Since, by definition, 'regular' verbs do not undergo vowel change in any inflectional variant, we searched for stems from outside the verb paradigm for all 'regular' verbs. For example, for the 'regular' verb kaufen (buy), we used the stem käuf, which is found in the noun Käufer (customer) or in the adjective käuflich (purchasable). In the case of 'regular' verbs, verbal and nonverbal stems differ via the application of 'umlaut' (Wiese, 
1996a, 1996b), which, in German, is represented by the graphemes ä, ö, and ü. These graphemes represent different phonemes than those represented by the graphemes $a, o$, and $u$, as the minimal pairs Bar (bar)-Bär (bear), losen (draw lots)-lösen (dissolve), and lugen (peek)-lügen (lie) show.

Assuming that stems are marked for grammatical category, the combination of a participle stem with a participle suffix is grammatically possible. Illegal combinations comprising an irregular participle stem can thus be considered as 'interpretable' according to the definition by Longtin and Meunier (2005). In contrast, the combination of a nominal stem with the participle affix is not only incorrect but also ungrammatical and can thus be considered as 'uninterpretable'. In our study, this is the case for both regular and irregular illegal combinations comprising a nonverbal stem. By means of these conditions we examined whether the meaning of stems in 'uninterpretable' formations is accessible.

These verbal and nonverbal stems (embedded in participle affixes) received carefully matched pseudostems (also embedded in participle affixes) as form controls. That is, a pseudostem, such as kaus or wenf, differed from the stem of the target (kauf or werf) by only one letter (in the rhyme) and by one or maximally two letters from the verbal or nonverbal stem of its corresponding illegal combination participle, such as käuf or wurf.

Given that illegal combination and pseudostem participles differ only in whether they comprise an existing stem or not-what would existing models predict for illegal combination and pseudostem participles? First, connectionist approaches have morphological regularities as implicitly evolving from the mapping of orthographic and semantic representations (Rueckl et al., 1997; Rueckl \& Raveh, 1999). Morphological priming is assumed to emerge as a result of systematic mappings between orthographic and semantic codes. This mapping is sensitive not only to whole-word units but also to sub-patterns within words that map systematically to similar semantic codes (Plaut \& Gonnerman, 2000; Raveh, 2002; Rueckl \& Raveh, 1999). The pseudostems used here retained more position-specific letters and were thus even more orthographically similar to the targets than the stems embedded in illegal combinations. Nevertheless, illegal combination participles contain existing stems, which consistently map into the same semantic activation when appearing in several real words. Therefore, illegal combination participles should prime verb targets to a greater degree than pseudostem participles that do not contain such a consistent unit.

Second, word-first models (e.g., Giraudo \& Grainger, 2000) agree that morphological information becomes available, but only after words are retrieved as whole units. Since neither illegal combination participles (gekäuft) nor pseudostem participles (gekaust) have lexical status, stems are not accessible, and no facilitation is expected. Third, morpheme-first models (e.g., Taft, 1994, 2004; Taft \& Forster, 1975) as well as dual route models that allow parsing and retrieval processes in parallel (e.g., Caramazza et al., 1988; Schreuder \& Baayen, 1995) predict that illegal combination participles are parsed into constituents. The former assume that parsing into morphemic constituents is an obligatory process for all complex forms, the latter only for items that do not possess a lexical representation. Thus, priming effects by illegal combination participles over and above form priming by pseudostem participles would provide strong evidence for parsing as an essential process in visual word recognition (e.g., Caramazza et al., 1988; Taft, 1979, 2004).

"Dual mechanism" approaches are specifically designed for the processing of inflection (e.g., Clahsen, 1999; Pinker, 1999; Sonnenstuhl et al., 1999). A default system parses and generates regularly inflected forms via rule. In contrast, irregularly inflected forms must be stored as whole words in the mental lexicon. If an irregular form, that is, an exception to the rule, cannot be retrieved from memory, the default will construct a 'regularized' form by applying this rule. The German default rule for the participle formation is assumed to suffix $-t$ to the base, which is the stem of the infinitive (Clahsen, 1999; Marcus et al., 1995). This combination (infinitive stem $+-t$ ) like gewerft is thus the only incorrect formation that the default may produce, and the infinitive stem should be the only stem that is accessible for irregular verbs.

In contrast to accessible default forms for irregular verbs, such as gewerft, we had two variants of illegal combination participles, those with stems from outside the verb paradigm and those with stems from within. Comparing effects of these two types can shed further light on the access codes of verb inflection. From a "dual mechanism" perspective, only stems of regular verbs such as kauf will be accessible, whereas the stems of originally irregular verbs such as worf will not. Some proponents of "dual mechanism" approaches assume that stems of irregular verbs may be accessible if they are combined with a regular affix, as is the case with irregular past tense forms. However, participles of irregular verbs, such as geworfen, are expected not to be decomposed since they do not contain a regular affix (e.g., Clahsen, Prüfert, Eisenbeiss, \& Cholin, 2002). Thus, according to these "dual mechanism" approaches, our nonword primes of irregular participle stems provide a strong test of decomposition: The stem worf should not be accessible, because the existing participle geworfen can only be retrieved as a whole unit. Hence, illegal combinations of regular participles, but not those of irregular participles may facilitate their related verb targets. However, if all stems exist as access codes regardless of verb class, both 'regular' and 'irregular' illegal combinations should prime related verbs. Moreover, 
because the prime itself does not require a response, priming effects by illegal combination participles would indicate that access to stems occurred regardless of task demands.

To summarize, our study pursued two main goals: (1) to assess whether inflection is processed by a single or a dual system by contrasting regular and irregular participle priming, and (2) to search for the type of access code used for regular and irregular verbs, by examining whether and how illegal combination participles facilitate a morphologically related target. If there is a single system for the processing of complex forms, there will be no difference in the priming by regular and irregular participles. Second, if parsing applies across the board so that constituent morphemes (and their meaning) are accessed, illegal combination participles should prime their verb targets. Moreover, if both of these assumptions hold, the priming of illegal combination participles will be equivalent to that of participle priming, and the priming of illegal combinations should be equivalent for those of originally regular and those of irregular participles.

\section{Method}

\section{Participants}

Thirty-eight university students participated in the experiment for course credit or payment. All were monolingual native speakers of German who had not been exposed to another language before the age of six. They were not dyslexic, and had normal or corrected-to-normal vision.

\section{Materials}

Appendix B lists all stimuli with their corresponding distributional variables. The stimulus material was con- structed with equal combinations of word/nonword primes paired with word/nonword targets. All primes - existing participles, illegal combination participles, and pseudostem participles - had the ge- prefix and either $-t$ or $-e n$ suffix. All targets were presented in the infinitive (stem and -en suffix), which is also the citation form in German.

\section{Targets}

The target stimuli were 88 monomorphemic German verbs, 44 with 'regular', and 44 with 'irregular 2' participle formation, which is the largest irregular class (see Table 1). Since our main interest was in participle priming, 'regular' and 'irregular 2' verbs were matched on participle surface frequency ( $\mathrm{PF}$, see prime description below and Table 2). All target verbs were presented in the infinitive (stem + -en suffix).

\section{Primes}

352 prime-target pairs were constructed by combining each of the 88 target verbs with two word and two nonword primes. Table 2 summarizes the characteristics of all prime types, including the number of items used, their mean participle surface frequency, mean lemma frequency, mean number of letters, and mean neighborhood size (type count).

\section{Word primes}

For each target verb, its corresponding participle was used as prime. All participles had the ge- prefix. 'Regular' and 'irregular 2' participles were of relatively low frequency and were matched on participle surface frequency (PF) and lemma frequency (LF), as indicated by CELEX (Baayen et al., 1993).

Each participle was paired with a control participle that was morphologically, orthographically, and seman-

Table 2

Prime characteristics

\begin{tabular}{|c|c|c|c|c|c|c|c|c|}
\hline \multirow[t]{3}{*}{ Example } & \multicolumn{4}{|c|}{ 'Regular' } & \multicolumn{4}{|c|}{ 'Irregular 2' } \\
\hline & \multicolumn{2}{|c|}{ Word primes } & \multicolumn{2}{|c|}{ Nonword primes } & \multicolumn{2}{|c|}{ Word primes } & \multicolumn{2}{|c|}{ Nonword primes } \\
\hline & $\begin{array}{c}\text { PT } \\
\text { (gezähmt) }\end{array}$ & $\begin{array}{c}\text { UPT } \\
\text { (gehallt) }\end{array}$ & $\begin{array}{c}\text { ICP } \\
\text { (gezahmt) }\end{array}$ & $\begin{array}{c}\text { PSP } \\
\text { (gezähst) }\end{array}$ & $\begin{array}{c}\text { PT } \\
\text { (gesponnen) }\end{array}$ & $\begin{array}{c}\text { UPT } \\
\text { (gepriesen) }\end{array}$ & $\begin{array}{c}\text { ICP } \\
\text { (gesponnt) }\end{array}$ & $\begin{array}{c}\text { PSP } \\
\text { (gespingen) }\end{array}$ \\
\hline$N$ & 44 & 44 & 44 & 44 & 44 & 44 & 44 & 44 \\
\hline $\mathrm{PF}$ & 5.6 & 6.5 & & & 5.7 & 6.8 & & \\
\hline LF & 27.4 & 31.3 & & & 42.1 & 85.8 & & \\
\hline Letters & 8.3 & 8.1 & 8.3 & 8.3 & 9.1 & 8.8 & 8.3 & 8.8 \\
\hline$N$-type & 1.5 & 2.4 & 2.7 & 2.0 & 1.7 & 2.0 & 1.8 & 1.0 \\
\hline
\end{tabular}

Note. Four different types of primes were used for each 'regular' or 'irregular 2' verb target: PT, participle of the target; UPT, unrelated participle; ICP, illegal combination participle (with nonverbal stems for 'regular' verbs'; nonverbal and correct participle stems for 'irregular 2' verbs), PSP, pseudostem participle. All frequencies are according to CELEX (Baayen et al., 1993). $N$, number of items used; PF, mean participle surface frequency per one million, LF, mean lemma frequency per one million; Letters, number of letters; $N$ type, number of neighbors per 6 million. 
tically unrelated to the target. A matched control participle belonged to the same verb class as the test participle, and thus possessed the same suffix. It was further matched on number of letters and neighbors. Most important, it was closely matched to its test participle on both surface and lemma frequency, either having the same or a slightly higher occurrence.

\section{Nonword primes}

An illegal combination participle was constructed for each target verb. Illegal combination participles for regular and irregular verbs were both constructed with a $-t$ suffix and differed only with respect to their stem.

Since 'regular' verbs never undergo stem alternation, all 44 illegal combination participles contained stems from outside the verb paradigm. For example, the stem $k a ̈ u f$, found in the noun Käufer (customer) and in the adjective käuflich (purchasable) was used to form the illegal combination gekäuft for the 'regular' verb kaufen (buy). In the case of 'regular' verbs, verbal and nonverbal stems differed via the application of 'umlaut' (see Wiese, 1996a, 1996b). Thirty-one of the 44 'regular' verbs, and hence also their correct participles, possessed an 'umlaut', as in gekämpft (fought), while their corresponding illegal participles stems, as in gekampft, did not, and vice versa for the other thirteen 'regular' verbs.

Two types of stems were used for 'irregular 2' verbs: 22 illegal combination participles contained the correct participle stem, such as stunk from gestunken (stunk), producing illegal gestunkt. For the other 22 irregular 2' verbs, a nonverbal stem, such as Schluss (closure, n.) was used, to create illegal combinations such as geschlusst. Importantly, this noun stem Schluss differs from all verbal stems of the 'irregular 2' verb schließen (close). There are only 22 'irregular 2' verbs for which a morphologically related nonverbal stem exists that is not part of the verbal paradigm, and which results in a nonword when combined with the participle affixes.

A control pseudostem participle was constructed for each illegal combination participle. First, the pseudostem differed from the stem of the target verb by only one letter: To keep the pseudostem as similar as possible to the original verb stem, a letter of the rhyme of the verb stem was exchanged. Second, the pseudostem differed from the stem of its matched illegal combination participle by maximally two letters. Pseudostem participles that were paired with illegal combination participles with nonverbal stems - all 'regular' types and half of the 'irregular 2' types-had a $-t$ suffix. The other half of 'irregular 2' types were suffixed -en. All pseudostem items in this study preserved the phonotactic constraints of German.

Stripping the ge-prefix off an illegal combination participle (e.g., geworft-worft) or a pseudostem participle (e.g., geworst-worst) did not lead to existing words.
To summarize, each verb target had four primes. The participle prime and the illegal combination participle possessed stems that were related to the target. The matched control participle was completely unrelated, and the pseudostem participle merely form-related to the target. Appendix B lists all targets and corresponding word and nonword primes. The four primes of a target were allocated to four lists by a Latin square design, yielding 88 experimental prime-target pairs on each list.

\section{Fillers}

176 prime-target pairs were included in each list as fillers. This had two purposes: first, to obtain the same number of word/nonword primes and word/nonword target pairs, and second, to reduce the proportion of related prime-target pairs to $16.6 \%$. All filler items differed from the experimental materials.

Forty-four verbs in the infinitive and 132 pseudostem verbs (e.g., karfen and strohlen) were used as targets, 88 existing and 88 pseudostem participles were used as primes. Of these, 22 participle primes and 22 pseudostem participle primes were combined with verb targets, and 66 participle primes and 66 pseudostem participle primes were combined with pseudostem verbs.

In total, each list comprised 264 prime-target pairs, 66 with word primes and word targets, 66 with word primes and nonword targets, 66 with nonword primes and word targets and 66 with nonword primes and nonword targets.

\section{Apparatus}

Stimuli were presented on a 17" monitor, connected to an IBM-compatible Pentium III personal computer. Response latency was recorded from the left and right 'control' keyboard keys.

\section{Procedure}

Participants were randomly assigned to one of four lists. Each list was further subdivided into four blocks of 66 trials each. The ordering of the prime-target pairs was randomized for each participant. Shuffling was repeated until maximally four word or nonword targets were presented consecutively.

Participants were tested individually in a dimly lit room, with a viewing distance of about $70 \mathrm{~cm}$ from the screen. There were twenty practice trials. Each trial started with the presentation of a fixation cross in the center of the screen for $1000 \mathrm{~ms}$. Then the prime was presented for $200 \mathrm{~ms}$, followed by an offset (blank screen) of $100 \mathrm{~ms}$ (SOA $300 \mathrm{~ms}$ ), after which the target appeared until a participant's response. The intertrial interval was $2000 \mathrm{~ms}$. Primes and targets were presented in the center of the screen in white Sans Serif letters on a 
black background. Primes were presented in uppercase 22-point letters, targets were presented in lowercase 26point letters.

Participants made lexical decisions to the targets and were instructed to respond as fast and as accurately as possible. Word responses were given with the index finger of the dominant hand, nonword responses with the index finger of the subordinate hand. Participants received feedback on the correctness of each response during practice trials, and on incorrect responses during the experimental session. After the response, either the word RICHTIG (correct) appeared in green uppercase letters, or FALSCH (incorrect) appeared in red uppercase letters, 28-point, for $500 \mathrm{~ms}$ (40 points) above the center of the screen.

The experiment lasted for $20 \mathrm{~min}$. Breaks between blocks were self-paced by participants.

\section{Results}

The data of two participants were removed (one participant due to extremely slow responses, mean $=1450 \mathrm{~ms}$, and one participant who closed her eyes to avoid seeing the primes), so that 36 participants were included in the data analyses. Means over word and nonword responses were calculated separately for each participant. Reaction times (RTs) exceeding 2 standard deviations from a participant's mean were excluded ( $4.1 \%$ of the critical data). Mean response latencies were calculated for correct responses; mean error rate was $3.7 \%$ for the critical trials. Table 3 provides the RT and error means as well as the corresponding effects.

Analyses were performed on RT and accuracy data with participants $\left(F_{1}\right)$ and items $\left(F_{2}\right)$ as random variables. In the following participant analyses $\left(F_{1}\right)$, all variables were treated as repeated measures factors; in the item analyses $\left(F_{2}\right)$, the variables Regularity ('regular'/ 'irregular 2') and Stem (nonverbal/participle) were treated as between items factors, all other variables as repeated measures factors. With each priming effect, we report its 95\% confidence interval (Masson \& Loftus, 2003).
Regular versus irregular participles: one or two systems?

The first question was whether regular and irregular participles prime their related base verbs to the same extent. For this purpose, latency and accuracy measures after word primes were entered in a two-way ANOVA with Regularity ('regular'/'irregular 2') and Relatedness (related/unrelated) as factors. The main effect of Regularity was not significant, neither with the latency data, $F_{1}(1,35)=2.26, p=.1420 ; F_{2}$ and $\min F^{\prime}<1$, nor with the accuracy data $\left(F_{1}, F_{2}\right.$, and $\left.\min F^{\prime}<1\right)$. In contrast, the main effect of Relatedness was significant with both the latency measure, $F_{1}(1,35)=48.63, \quad p<.0001$; $F_{2}(1,86)=43.63, \quad p<.0001, \quad \min ^{\prime}(1,104)=22.99$, $p<.0001$, and the accuracy measure, $F_{1}(1,35)=7.78$, $p=.0085 ; \quad F_{2}(1,86)=6.60, \quad p=.0119 ; \quad \min ^{\prime}(1,106)$ $=3.570, p=.0616$. Responses for verb targets following related participles ( $557 \mathrm{~ms} ; 3.0 \%$ ) were recognized faster $(53 \pm 17 \mathrm{~ms})$ and with fewer errors $(2.3 \pm 3 \%)$ than those following an unrelated participle $(610 \mathrm{~ms} ; 5.3 \%)$. Most important, the interaction was not significant on any measure (all $F_{1}, F_{2}$, and $\min F^{\prime}<1$ ). This clearly confirmed that the priming of 'regular' participles ( $54 \pm 17 \mathrm{~ms} ; 1.3 \pm 3 \%$ ) was equivalent to that of 'irregular' participles $(52 \pm 17 \mathrm{~ms} ; 3.4 \pm 3 \%)$.

\section{Illegal combination participles: decomposition or whole word access?}

The second aim of this study was to examine whether nonwords, that is, illegal combination participles, can facilitate the recognition of a following verb target, and whether illegal combinations that originate from both regular and irregular participles can produce such facilitation. Response latencies and accuracies after nonword primes were entered in a two-way ANOVA with the factors Regularity ('regular'/'irregular 2') and Relatedness (related/unrelated), where illegal combination participles represented the related nonwords and pseudostem participles the unrelated nonwords. There was no main effect of Regularity on any measure (all $F_{1}, F_{2}$, and $\left.\min F^{\prime}<1\right)$. The main effect of Relatedness was significant with the latency measure, $F_{1}(1,35)=$

Table 3

Mean RT in ms and error percentage (SD in parentheses) for 'regular' and 'irregular 2' verb targets preceded by word and nonword primes

\begin{tabular}{|c|c|c|c|c|c|c|c|c|}
\hline \multirow[t]{3}{*}{ Relatedness } & \multicolumn{4}{|c|}{ Word primes } & \multicolumn{4}{|c|}{ Nonword primes } \\
\hline & \multicolumn{2}{|c|}{ 'Regular' } & \multicolumn{2}{|c|}{ 'Irregular 2' } & \multicolumn{2}{|c|}{ 'Regular' } & \multicolumn{2}{|c|}{ 'Irregular 2' } \\
\hline & RT & Error & RT & Error & RT & Error & RT & Error \\
\hline Unrelated & $615(132)$ & $5.3(6.9)$ & $606(116)$ & $5.4(8.0)$ & $603(121)$ & $2.3(4.7)$ & $595(128)$ & $3.7(5.4)$ \\
\hline Related & $561(118)$ & $4.0(6.4)$ & 554 (113) & $2.02(5.4)$ & $570(117)$ & $4.0(7.5)$ & $566(114)$ & $2.6(5.1)$ \\
\hline Effect & 54 & 1.3 & 52 & 3.38 & 33 & -1.7 & 30 & 1.1 \\
\hline
\end{tabular}


$18.72, p<.0001 ; F_{2}(1,86)=13.26, p=.0005 ; \min ^{\prime}(1$, $112)=7.761, p=.0063$, though not with the accuracy measure $\left(F_{1}, F_{2}\right.$, and $\left.\min F^{\prime}<1\right)$. Illegal combination participles $(568 \mathrm{~ms})$ significantly facilitated responses relative to merely form-related pseudostem participles (599 ms). Thus, morphologically-related stems facilitated the processing of the following target, even if embedded in a nonword. Again, the interaction was not significant, neither with latency $\left(F_{1}, F_{2}\right.$, and $\left.\min F^{\prime}<1\right)$ nor with accuracy data, $F_{1}(1,35)=2.27, p=.1410 ; F_{2}(1,86)=2.95$, $p=.0894 ; \min ^{\prime}(1,88)=1.282, p=.2605$. Clearly, priming effects were equivalent for illegal combinations that originated from 'regular' participles $(33 \pm 17 \mathrm{~ms})$ and those from 'irregular 2' participles ( $30 \pm 17 \mathrm{~ms})$.

Next, priming for illegal combinations that originated from 'irregular 2' verbs was examined in more detail. Half of these included the correct participle stem (as in gestunkt), whereas the other half contained a nonverbal stem (as in gewurft). The question was whether both types of stem contributed to the overall priming effect. A twoway ANOVA with Relatedness (related/unrelated) and Stem (participle/nonverbal) was conducted for this subset. As expected, there was a main effect of Relatedness, $F_{1}(1,35)=11.42, p=.0018 ; F_{2}(1,42)=6.68, p=.0133$; $\min F^{\prime}(1,117)=4.214, \quad p=.0436$. The nonsignificant main effect of Stem, $F_{1}(1,35)=1.45, p=.2361 ; F_{2}$ and $\min F^{\prime}<1$, together with the absence of an interaction $\left(F_{1}, F_{2}\right.$, and $\left.\min F^{\prime}<1\right)$ showed that reactions to 'irregular 2 ' targets were equally facilitated, whether the prime contained a nonverbal stem $(34 \pm 21 \mathrm{~ms})$ or the correct participle stem $(26 \pm 21 \mathrm{~ms})$.

\section{Word participles versus illegal combination participles}

To examine whether the priming effects of illegal combination participles were equivalent to those of existing participles, a two-way ANOVA with Prime Lexicality (word/nonword) and Regularity ('regular'/'irregular 2') was performed on difference scores (unrelatedrelated), calculated for latency and accuracy measures.

The main effect of Regularity was not reliable for response latencies $\left(F_{1}, F_{2}\right.$, and $\left.\min F^{\prime}<1\right)$, and marginally significant with the accuracy measure, $F_{1}(1,35)=3.20, p=.0823 ; F_{2}(1,86)=4.15, p=.0448$; $\min F^{\prime}(1,88)=1.806, p=.1824$, nor was the interaction significant $\left(\right.$ all $F_{1}, F_{2}$, and $\left.\min F^{\prime}<1\right) .^{5}$ This confirms

\footnotetext{
${ }^{5}$ This main effect of Regularity for error data combines the responses for verb targets following both word and nonword primes. It states that regular verb targets following participles and illegal combination participles are responded to slightly more accurately than irregular verb targets following participles and illegal combination participles. Since this finding does not allow any theoretical conclusions regarding decomposition vs. retrieval or regarding single vs. dual systems, we do not discuss this effect in detail.
}

that, overall, 'regular' and 'irregular 2' verbs were primed to the same extent. The main effect of Prime Lexicality was marginally significant with both the latency data, $F_{1}(1,35)=3.82, p=.0586 ; F_{2}(1,86)=3.48, p=$ $.0655 ; \min F^{\prime}(1,103)=1.821, p=.1802$, and the accuracy data, $F_{1}(1,35)=4.54, p=.0401 ; F_{2}(1,86)=3.75$, $p=.0562 ; \min F^{\prime}(1,107)=2.053, p=.1548$. Participle priming ( $53 \pm 22 \mathrm{~ms} ; 2.3 \pm 2.7 \%$ ) was slightly more efficient than the priming of illegal combination participles $(31 \pm 22 \mathrm{~ms} ;-0.39 \pm 2.7 \%)$.

In the above comparison, responses following related word primes were subtracted from those following unrelated word primes, and responses following illegal combination participles were subtracted from those after unrelated nonword primes (i.e., pseudostem participles). To compare our findings to those of Longtin and Meunier (2005) who measured related word priming and related nonword priming with reference to the same baseline, namely, unrelated word primes, in the following analyses we calculated the priming of participles and illegal combination participles relative to the same baseline, namely unrelated word participles. A two-way ANOVA with Prime Lexicality (word/nonword) and Regularity ('regular'/ 'irregular 2') was run on difference scores, calculated for latency and accuracy measures.

As in all other analyses, neither the main effect of Regularity nor the interaction were significant, neither on the latency nor on the accuracy measure (all $F_{1}, F_{2}$, and $\left.\min F^{\prime}<1\right)$. Most important, the main effect of Prime Lexicality was neither significant with the latency data, $\quad F_{1}(1,35)=2.03, \quad p=.1634, \quad F_{2}(1,86)=1.16$, $p=.2846, \min F^{\prime}<1$, nor with the accuracy data $\left(F_{1}\right.$, $F_{2}$, and $\left.\min F^{\prime}<1\right)$. This clearly indicates that - when compared with the same baseline - the recognition of a related verb target was facilitated to the same degree by correct participles $(53 \pm 13 \mathrm{~ms} ; 2.3 \pm 1.9 \%)$ as it was by illegal combination participles $(43 \pm 13 \mathrm{~ms}$; $2.0 \pm 1.9 \%$ ). Fig. 1 depicts these word and nonword priming effects separately for regular and irregular verbs.

Pseudostem participles versus unrelated word participles: is there a form effect?

The above analyses showed that illegal combination participles were equivalent to the real participles as primes when compared with the same baseline of unrelated word participles, but not when compared with pseudostem participles. Note that the pseudostems (kaus in gekaust) were a close match for the target stem (kauf in kaufen), whereas the stems of the unrelated participles (prüf in geprüft) were not.

In order to examine whether the pure form similarity of pseudostems influenced target recognition, we ran a two-way ANOVA with the factors Regularity ('regular'/'irregular 2') and Form (similar/dissimilar), with 


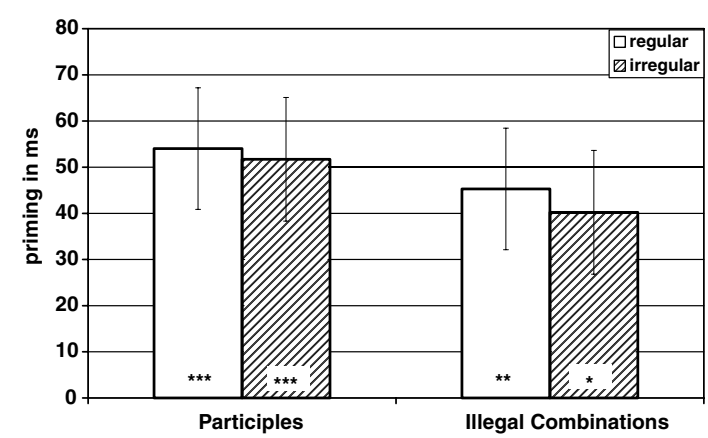

Fig. 1. Priming of participles and illegal combination participles (relative to unrelated word participles) for regular and irregular verbs. ${ }^{*} p<.01,{ }^{* *} p<0.001$, and ${ }^{* * *} p<.0001$ indicate the significance levels of the priming effects in both participants and items analyses; y-bars provide the $95 \%$ confidence intervals of the priming effects.

pseudostems comprising the similar stems and unrelated word participles representing the dissimilar stems.

There were no significant effects for the latency data: Neither the main effect of Form, $F_{1}(1,35)=2.34$, $p=.1354 ; \quad F_{2}(1,86)=2.40, \quad p=.1249 ; \min ^{\prime}(1,98)=$ $1.184, p=.2791$, nor the main effect of Regularity, $F_{1}(1,35)=1.52, p=.2254 ; F_{2}$ and $\min F^{\prime}<1$, nor the interaction $\left(F_{1}, F_{2}\right.$, and $\left.\min F^{\prime}<1\right)$ were significant. However, the main effect of Form was significant with the accuracy measure, $F_{1}(1,35)=7.08, p=.0117 ; F_{2}(1,86)=$ 4.96, $\quad p=.0285 ; \quad \min F^{\prime}(1,113)=2.916, \quad p=.0905$. Together with the nonsignificant main effect of Regularity and the nonsignificant interaction (all $F_{1}, F_{2}$, and $\left.\min F^{\prime}<1\right)$, this indicates that verb targets were recognized more accurately when they were preceded by pseudostem participles with orthographically similar stems $(2.9 \%)$ than when they were preceded by unrelated word participles holding dissimilar stems $(5.3 \%)$. That is, meaningless, but form-related nonword controls increased the accuracy of target recognition (by $2.4 \pm 1.8 \%$ ) relative to word controls.

\section{Discussion}

This study pursued two goals: first, to examine whether one or two systems are required for the processing of regular and irregular inflection, and second, to explore whether whole words or morphemic constituents represent the access codes of regular and irregular inflection.

\section{Regular versus irregular participles: one or two systems?}

With respect to the first issue, we compared the priming effects of regular and irregular participles. Similar priming effects can be taken as evidence for a single sys- tem for both verb classes, whereas different priming effects may necessitate the postulation of a dual system. This was the logic of the study by Sonnenstuhl et al. (1999).

As mentioned earlier, regular and irregular verbs are of different type and token frequency. Furthermore, regular participles suffixed with the single letter - $t$ are, on the whole, shorter than irregular participles with the suffix -en. It is thus almost impossible to closely match regular and irregular participles on confounding variables like surface frequency, lemma frequency, suffix, letter length, and number of neighbors. We therefore closely matched each regular and irregular participle with a baseline participle on all of these variables.

The results are straightforward: 'Regular' participles (gekauft) primed their base verbs (kaufen) to the same degree as 'irregular 2' participles (geworfen) primed their base verbs (werfen; 54 and $52 \mathrm{~ms}$, respectively). This result replicates previous findings in Italian (Orsolini \& Marslen-Wilson, 1997), French (Meunier \& MarslenWilson, 2004), and German (Smolka et al., 2003). The size of the participle priming effects obtained here strikingly resembles the effects reported in Smolka et al. (2003), where low-frequency 'regular' participles produced a priming effect of $48 \mathrm{~ms}$ and 'irregular 2' participles a priming effect of $47 \mathrm{~ms}$. In fact, even the one study on German participle priming that argues for a "dual mechanism" model (Sonnenstuhl et al., 1999) observed equivalent priming by 'regular' $(30 \mathrm{~ms})$ and 'irregular 1' (25 ms) participles. As discussed earlier, the critical interaction reported there was not due to different participle priming but rather due to differences in identity priming. Overall, evidence across these different languages converges that regular and irregular participles prime the recognition of their base verbs to the same degree.

In English, several studies showed different priming patterns for regular and irregular verbs (Marslen-Wilson, 1999; Napps, 1989; Stanners et al., 1979). However, a recent study demonstrated that the amount of participle priming depended on the form overlap between a participle and its base (Pastizzo \& Feldman, 2002): Fully form overlapping (regular) participles produced the strongest priming effect, partially overlapping (irregular) participles yielded a weaker effect, and participles with the least form overlap did not yield priming. Such graded effects suggest that a single system processes regular and irregular participles. These and our findings are compatible with the assumption of some connectionist models (Seidenberg \& Arnoldussen, 2003; Westermann, 2005) that any processing differences between regular and irregular verbs may reflect a distinction along distributional variables rather than a grammatical distinction. Obviously, besides the grammatical distinction of regularity versus irregularity, verbs may differ along many dimensions that affect their processing, such as 
frequency, letter length, number of neighbors, spelling to sound correspondences, and the like. Using German participles, Westermann (2005) showed that his constructivist neural network model developed an additional structure mainly for irregular participles, which resulted in a dissociation between regular and irregular verbs. However, this dissociation between regular and irregular verbs was better described in terms of a continuum between verbs that are easy to process and those that are hard to process rather than by the grammatical distinction.

These modeling data are compatible with our priming data: Regular and irregular participles produced the same amount of priming, when many distributional variables were controlled. Together, the results provide strong evidence against a dichotomy in terms of regular and irregular inflection. Given that a single system can adequately explain the processing of regular and irregular inflection, there is no need to postulate principally different systems.

\section{Illegal combination participles: decomposition or whole word access?}

Participle priming patterns may reveal how many systems need to be postulated, but not what kind of processes operate within a system, namely, whether participles are parsed or retrieved. Our second aim thus was to examine the nature of the access codes for inflected words: whole words or morphemic constituents? Participants saw illegal combination participles (gekäuft) before they responded to a verb target (kaufen). Since illegal combination participles do not exist and cannot be retrieved from memory, only their stem $(k \ddot{a} u f)$ is morphologically related to the verb target. Hence, any priming of the verb target must originate from the activation of the stem of the illegal combination and can be taken as evidence that the constituents of the illegal combination were accessed. This is exactly what the results demonstrated: Illegal combination participles (gekäuft) clearly facilitated the recognition of verb targets ( $k a u-$ $\mathrm{fen}$ ), relative to the form-related pseudostem participles (gekaust).

In the present study, participants were consciously aware of the prime ( $300 \mathrm{~ms}$ SOA). Moreover, all primes consisted of participle formations with a ge- prefix and either the $-t$ or the $-e n$ suffix. Thus, participants may have applied a strategy to decompose the illegal combination participles into their constituent units. Therefore, we cannot establish whether the decomposition of illegal combination participles ocurred automatically or not.

Nevertheless, such nonword priming is problematic for word-first models (Butterworth, 1983; Giraudo \& Grainger, 2000, 2001; Henderson, Wallis, \& Knight, 1984). Priming by illegal combination participles rather supports models that assume morphemic access units in the mental lexicon (e.g., Caramazza et al., 1988; Schreuder \& Baayen, 1995; Taft, 2004). They agree well with evidence from French, where derivational illegal combinations produced the same amount of priming as did existing derived words with the same stem (Longtin \& Meunier, 2005). This even held when stem and suffix were incompatible with respect to grammatical category. For example, the French suffix -eur may be attached to verbs or adjectives, but not to nouns, so that the illegal combination denteur is an ungrammatical combination and was thus classified as 'uninterpretable' by the authors.

Similarly, most illegal combination participles used here were ungrammatical and 'uninterpretable' combinations: Nonverbal stems derived from nouns or adjectives, such as küuf, cannot be grammatically combined with participle affixes. Nevertheless, these ungrammatically embedded stems facilitated the recognition of verb targets to the same degree as stems from within the verb paradigm. Apparently, the word-category to which the stem belongs is irrelevant. Priming is observed, as long as parsing provides an existing stem whose meaning can be accessed. Our data thus show that even completely unpredictable and 'uninterpretable' forms are decomposed.

To summarize, our findings provide further evidence in favor of a single system that decomposes complex forms into constituent units in an effort to extract meaning from these constituents (see our model below).

\section{Illegal combinations of regular and irregular participles}

We further showed that meaning is extracted from stems of both regular and irregular inflection. Illegal combination participles such as geküuft, originating from regular verbs, and illegal combinations such as geworft, originating from irregular verbs, produced equal priming ( 33 and $30 \mathrm{~ms}$, respectively).

"Dual mechanism" models (e.g., Clahsen et al., 2001; Pinker, 1998) incorporate different access procedures and thus predict different facilitation for regular and irregular verbs. Stems of regular verbs can be accessed, but not those of irregular verbs. Thus, illegal combination participles derived from regular verbs should prime a morphologically related target, those from irregular verbs should not. Evidently, the fact that illegal combinations of both regular and irregular participles showed equivalent facilitation strongly disagrees with the idea of two systems.

Advocates of a "dual mechanism" account may argue that all types of nonwords, hence also illegal combination participles and pseudostem participles, are expected to be decomposed: If a word cannot be retrieved from memory, the system will assume that it must be a regularly inflected item that requires decomposition. But parsing will result in irregular stems, such 
as worf, which are not supposed to be represented, if irregularly inflected participles are not decomposed and exist only as whole words (e.g., Clahsen et al., 2002). The use of nonword primes with stems of irregular participles thus provided a strong test for stem access in our experiments.

Furthermore, "dual mechanism" models (e.g., Clahsen, 1999; Pinker, 1998) permit the default system to generate an inflected form for irregular verbs, if the storage system does not provide an existing form. Since the default for German participle formation is assumed to combine the infinitive stem with the $-t$ suffix, an illegal combination like gewerft should be the only form in which the stem of an irregular verb like werfen is accessible. Yet, we found priming effects of illegal combinations of originally irregular participles, independent of suffix type and vowel alternation. Our results thus demonstrate that other combinations besides the default combination are parsed, and other stems besides the infinitive stem are accessible as separate units in the mental lexicon, no matter whether these stems belong to regular or irregular verb inflection. This provides strong evidence against an inborn default system, as assumed by "dual mechanism" models.

\section{Word participles versus illegal combination participles}

How do priming effects of illegal combination participles and existing participles compare? When calculated relative to pseudostem primes (gekaust), which held a stem that was orthographically very similar to the target stem (kauf), effects of illegal combination participles (gekäuft) were somewhat smaller than those of correct participles. However, when calculated relative to the same baseline, that is, an unrelated existing participle (geprüft), the priming of illegal combination participles (43 ms) was equivalent to that of existing participles (53 ms).

These two different baselines - an orthographically similar nonword prime and an unrelated word primerevealed two aspects: the influence of orthographic similarity and the strength of morphological relations. First, nonword primes with pure form overlap activate the target's stem to some degree, as was revealed in a significant effect with the error data. Pseudostem participles (gekaust) and unrelated participles (geprüft) share the same participle affixes, so that any facilitation by pseudostem participles can be attributed to the form similarity between pseudostems (kaus) and target stems (kauf). This small form effect is compatible with the idea that early visual word recognition is based on orthographically motivated segmentation (Rastle, McCormick, \& Davis, 2005), and with connectionist models which postulate that meaning activation is subserved by the activation of orthographically analogous units (Plaut \& Gonnerman, 2000; Rueckl \& Raveh, 1999).
Second, the finding that nonwords and words produce equivalent priming as long as the stems of prime and target are morphologically related, demonstrates a morphological effect: Stem morphemes are accessed and activated for meaning, and this occurs regardless of the overall lexicality of the prime. As stated earlier, these results agree well with data from Longtin and Meunier (2005) for derived nonword combinations in French. Since these authors used masked priming conditions, under which participants were unaware of the prime, Longtin and Meunier concluded that morphemic units are extracted automatically and very early in visual word recognition.

Could it be that effects of illegal combination participles are due to orthographic rather than morphological similarity? Connectionist models assume that "morphologically related words have similar and overlapping patterns of activation over form and semantic processing units" (Raveh, 2002, p. 322). Morphological regularities are assumed to emerge as the result of statistical regularities between form and meaning overlap, which are represented at hidden layers between orthographic and semantic codes (Plaut \& Gonnerman, 2000; Raveh, 2002; Rueckl \& Raveh, 1999).

For regular verbs, the stems of pseudostem participles (gekaust) and those of illegal combination participles (gekäuft) shared the same number of letters with the stem of the verb target (kaufen). With regard to irregular verbs, our data showed that the orthographic-to-semantic meaning mappings may include units that are orthographically very dissimilar from the original units: zug and zog from zieh, or waag and wog from wieg. Thus, from the viewpoint of position-specific letter nodes (Rueckl \& Raveh, 1999), illegal combinations like gezugt (instead of correct gezogen, pulled) or gewaagt (instead of correct gewogen, weighed), had even less orthographic similarity to the targets' stems zieh and wieg than the matched pseudostem participles gezient and gewiebt. Nevertheless, illegal combination participles significantly primed responses relative to these pseudostem participles. This facilitation clearly demonstrates that morphological regularities in German go beyond form-to-meaning mappings. It is debatable whether such abstracted units must be explicitly represented or may be captured via hidden units. At present, we prefer to think of them as explicit morphological units in order to emphasize their possible dissimilarity in form.

Therefore, we interpret our findings in terms of an initial segmentation process that is orthographically motivated, but that activates the smallest meaningful units: morphemic constituents. This activation becomes independent of form and occurs whenever the system has the opportunity to extract meaning.

To summarize, this study explored whether regular and irregular inflection is processed by a single or a dual 
system. Equivalent regular and irregular participle priming argues for a single system. Second, we asked whether participles are retrieved as whole-word units or whether they are accessed via their morphemic constituents. Priming of illegal combination participles showed that the meaning of stems is accessed. Moreover, the priming of illegal combination participles was equivalent to the priming of existing participles, indicating that stems are accessed for meaning regardless of whether they are embedded in existing words or nonexistent formations. Furthermore, both word and nonword priming was equivalent for regular and irregular inflection, confirming that stems are accessed for meaning irrespective of whether they originate from regular or irregular inflection. Finally, the same amount of priming by illegal combination participles comprising verbal stems and those comprising nonverbal stems indicated that stems activate the same meaning concepts regardless of their grammatical category. These findings are captured in the model below.

\section{The model}

Fig. 2 depicts the outline of a single system for visual word recognition. Most important, the same processes apply regardless of whether the input consists of existing or nonexistent, regular or irregular forms, interpretable or 'noninterpretable' forms. We assume that the input comprises orthographic codes that are mapped onto semantic codes by means of an intermediate layer that captures these form-to-meaning mappings.

The initial process partitions orthographic strings into frequently encountered segments such as bigrams or trigrams, which are mapped onto meaning. Indeed, our findings showed that meaningless but form-related pseudostems, such as kaus in gekaust, facilitated the recognition of targets such as kaufen. This form-to-meaning mapping is reiterated until the most successful mapping is reached, which will correspond to the small-

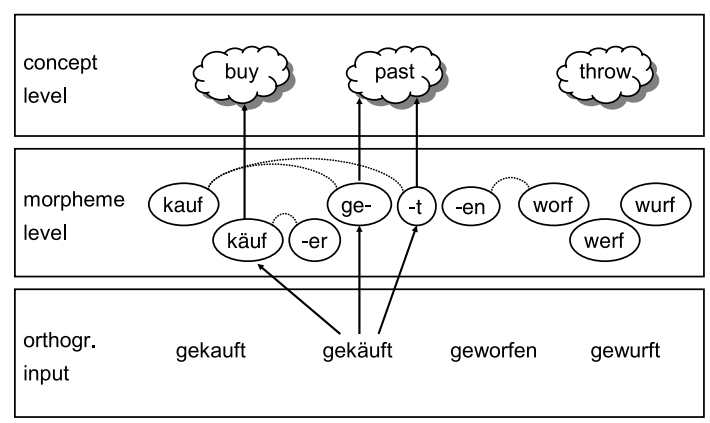

Fig. 2. A single system model as applied to the processing of regular and irregular inflection (see text for further details.) est meaningful units: morphemic constituents. Thus, orthographic strings like gekauft, gekäuft, geworfen, and gewurft, are segmented into their constituent morphemes: ge-, kauf-, worf, käuf-, wurf, -t, -en.

Similar to connectionist models, we assume that orthographic codes are mapped onto meaning codes via an intermediate layer. This intermediate layer comprises morphological regularities, that is, statistical regularities between form and meaning overlap that determine the performance of the system: the more morphological regularities (i.e. form and meaning overlap), the faster and more efficient the system (Rueckl \& Raveh, 1999). However, the question is whether morphemic constituents are explicitly represented or not.

As discussed above, the stems that relate to a particular concept, such as the stems werf, worf, wurf relating to the concept throw or the stems zieh, zog, and zug relating to pull, may vary substantially in their orthographic overlap. This means that the form-to-meaning mapping becomes progressively independent of form, allowing the variation of orthographic relatedness across morphemic units. A connectionist model could assume hidden units that capture variations of the vowel as in werf, worf, wurf by a common representation such as W_RF. However, since the orthographic variance at hand may include most of the stem as in the example zieh, zog, zug, we prefer to emphasize the orthographic dissimilarity that the units may span by having the abstracted form-to-meaning mappings explicitly represented as morphological units.

The meaning of these morphemes is accessed and corresponding concepts at the concept level are activated. For example, the unit ge- of the input string gekauft activates the meaning of past (in its function as participle prefix ${ }^{6}$ ), the unit $-t$ activates the meaning of past (in its function of participle suffix), as well as the meaning of present (for 3 rd person singular or 2 nd person plural). Among these different activations, the concept past will yield the highest activation by the combined units $g e$ - and $-t$. The unit kauf will activate the concept buy. Together, activations of buy and past will give rise to the meaning of bought.

The same principle holds for nonword formations such as the illegal combination gekäuft, which provides access to the affixes ge- and $-t$ as well as to the (nonverbal) stem käuf at the morpheme level, which will activate the concept buy. Again, the combined activations of buy and past will produce the meaning of bought. Thus, the item gekäuft activates the same concepts as the correct

\footnotetext{
${ }^{6}$ This assumption holds even though the prefix ge- is phonologically motivated. Also uninflected monomorphemic verbs that start with the letter cluster ge-, such as geschehen (happen) or gewinnen (win), will activate the meaning past. However, the combined activation of ge-scheh and ge-winn will activate their meanings happen and win, respectively.
} 
item gekauft. Regardless of whether the input represents existing or nonexistent formations, this activation will prime another concept-related target verb like kaufen.

In contrast to the assumptions of a "dual mechanism" account that irregularly inflected participles are accessed as whole words (e.g. Clahsen, 1999), the present model suggests that the parsing process is the same for irregular participles like geworfen. The units ge-, worf, and $-e n$ are accessed, which activate the concepts throw and past, jointly generating the meaning thrown. However, if no stem exists, as wors in the pseudostem participle geworsen, the only activation at the concept level is that produced by the affixes, which activate the concept past. Although the form similarity of the pseudostem can activate the meaning of a form-related word to some degree - as observed in this study - this activation is not sufficient to fully activate the concept throw.

The model thus predicts that all existing stems, regardless of whether they belong to a regular or an irregular participle, are accessed and activate their corresponding concepts. Our data demonstrate that these stems do not even require word status. Rather, similar to abstract root morphemes in Hebrew (Frost et al., 1997, Exp. 3), stems are lexically represented and serve as lexical units.

It is possible that the kind of morphological decomposition described here applies to German, Italian, and French irregular inflections, since they are concatenated, but not to English irregular inflection which is not. The present model assumes that also in English those constituents that represent meaning will be abstracted from orthographic strings. For example, the orthographic strings dealt, grown, and stolen will be segmented into their constituent morphemes deal, grow, and stole, which will activate their underlying concepts. What about those irregular forms that do not preserve the morphemic boundaries? A strong morphological model would assume that even an orthographic string like taught is segmented into taugh and $-t$, however, this remains to be tested in future experiments, probing whether illegal combinations such as taughen, taughed, grewed, grewn, sinken, sanked, or stealed, stealen, and stoled active their corresponding base verbs.

\section{The organization of stems}

Stems are organized according to their meaning and independent of word category. All verbal stems such as werf, worf, warf, and wirf, together with the nonverbal stem wurf, activate the same concept throw, and the verbal stem kauf activates the same concept as does the nonverbal stem käuf. As exemplified above, the assumption that an illegal combination participle such as gewurft activates the same concept throw as does the correct participle geworfen can explain why these two items prime the following verb target werfen to the same degree.

Because different stem variants relate to the same concept, and because they need not be marked for syntactic category, a further consequence emerges for the model: Each stem exists only once, there are no different lemmas for the same form of a stem. It is the same stem kauf that is used in the inflected verb form in combination with participle suffixes, gekauft, in derived verbs, such as abkaufen (buy sth. from so.), ankaufen (buy), verkaufen (sell), in deverbal nouns, such as Kauf (buy, $\mathrm{n}$.), complex adjectives, such as kaufenswert (worth buying), or complex nouns, such as Kaufhaus (department store) or Hauskauf (purchase of a house). The assumption of a single stem regardless of syntactic category differs from previous models assuming that stems are marked for their syntactic category (e.g. Caramazza et al., 1988; Niswander, Pollatsek, \& Rayner, 2000; Schreuder \& Baayen, 1995). For example, Taft (2004) assumes that "different parts of speech of a word will be represented by different lemmas linked to the same form units". That is, in his model, there is a separate lemma for the noun and verb versions of kauf, and each of these has its own frequency of occurrence, so that the frequency of the verb lemma for $k a u f$ will differ from the frequency of the noun lemma for kauf or the adjective lemma for kauf. However, such a distinction may become rather difficult in cases of complex forms, such as compounds, deverbal nouns, denominal adjectives, and the like. In contrast, the present model assumes that the frequency of the stem kauf is represented by the frequency of all (orthographically identical) forms kauf encountered in the lexicon.

Although this was not directly tested here, the model predicts that the frequency of a single constituent will influence the word recognition process. Previous findings repeatedly showed that word responses were influenced by the frequency of a word's stem, that is, by the frequency of all other words sharing that stem. With surface frequency matched, words with high-frequency stems were recognized faster than words with low-frequency stems (e.g. Baayen, Dijkstra, \& Schreuder, 1997; Bertram, Schreuder, \& Baayen, 2000; Burani \& Caramazza, 1987; Taft, 1979, 2004).

Similar to word responses, also nonword responses should be influenced by the frequency of the stem, though in the opposite direction: High-frequency stems in nonwords should decelerate nonword responses in comparison to low-frequency stems. Taft and Forster (1976, Exp. 5) compared nonwords comprised of highfrequency constituents, such as stonefoil, and nonwords comprised of low-frequency constituents, such as stalegrip: Nonwords with a high-frequency constituent produced slightly slower responses than those with a low-frequency constituent. In spite of the fact that this effect was interpreted differently by the authors, it 
supports the predictions of the present model that the frequency of the stem should affect nonword decisions. Correspondingly, an illegal combination participle such as gekaufen that holds the highly familiar stem kauf (type frequency of 525 and a token frequency of 3367) should seem more word-like and thus more difficult to reject as nonword than an illegal combination participle as gekäuft comprising the lower frequent stem käuf (type frequency of 81 and a token frequency of 401). ${ }^{7}$

\section{Stem-affix combinability}

Speakers of a language mostly produce correct combinations and are able to decide which combinations are correct. Hence, the model predicts that besides the frequency of the stem also the frequency of a particular stem-affix combination will influence the word recognition process. The question is where and how the information about the stem-affix combinability is stored, if it is stored at all. One option is the assumption of a wholeword level, to which the stem-affix combination is compared, as in early models of decomposition (Taft, 1979, 1981; Taft \& Forster, 1975; Taft, Hambly, \& Kinoshita, 1986) and more recent interactive activation models (Colé, Segui, \& Taft, 1997; Taft, 1994). Another possibility is to assume explicit rules that specify the stem-affix combinability for regular inflections (e.g. Taft, 2004) or other specifications, such as inhibitory links of irregular stems to regular participle suffixes (e.g., Caramazza et al., 1988). The proposed model neither requires a whole-word level nor explicit rules. Rather, the legality of a combination is determined by the frequency of certain combinations that are encountered during language learning and language use. That is, the connections between stems and affixes represent the information about the correct form of the whole word, though in a flexible way, since these connections are acquired according to the frequency in which particular combinations occur. They can as well be lost again with diminishing occurrence. For example, in modern German many low-frequency irregular participles are replaced by new combinations (mostly of the infinitive stem and the $-t$ suffix), such as gewringt replacing gewrungen (wrung), or may coexist alongside with new combinations, such as (original) gequollen (flowed) and the newer form gequellt. This flexible representation at the morpheme level allows us to explain how certain 'correct' forms can either coexist with new combinations or be replaced by them.

Moreover, stem-affix combinations can be swapped in nonstandard language. The stem käuf is normally encountered with suffixes -er or -lich to perceive or pro-

\footnotetext{
${ }^{7}$ Stem counts are per one million and include all orthographically identical forms of the Mannheim Corpus, CELEX, Baayen et al., 1993, regardless of syntactic category.
}

duce the concepts someone who buys, as in Käufer (customer), or something that can be bought, as in käuflich (purchasable). However, exposure to the unorthodox use of gekäuft as participle, indicating the concepts buy and past, will soon strengthen the connections between the stem $k \ddot{a} u f$ and the affixes ge- and - $t$ at the morpheme level. Indeed, a search in Google indicates that the form gekäuft is frequently used, mostly in a context marking nonstandard language usage. The stem käuf has been continuously used in several dialects since Lower German, as in verkäufen, though not in participle formations (Digital Wenker-Atlas, 2005).

\section{The default combination}

As discussed above, the present model suggests that two factors determine the learning algorithm for the processing of participles: the frequency of the constituents and the frequency of the combination. At least with German participles, the combination of the most frequent stem, namely, the infinitive stem, together with the most frequent participle suffix, namely, the $-t$ suffix, and the most frequent combination type, namely, the combination (infinitive/- $t$ ), will lead to the production of a 'default' combination if no other combination is available. Consider, for instance, the verb werfen (throw) and its irregular participle formation geworfen (thrown), which possesses a surface frequency of 115 . Regarding the different stem types of werfen, the infinitive stem werf has a type frequency of 328 and a token frequency of 620 , the correct participle stem worf has a type frequency of 72 and a token frequency of 473, the preterit stem warf has a type frequency of 171 and a token frequency of 154, and the present stem wirf has a type frequency of 104 and a token frequency of $232 .^{7}$ With regard to the participle combination type, for monomorphemic verbs, the combination (infinitive/- $t$ ) has a type frequency of roughly 1700 , whereas the combination (infinitive/-en) has a type frequency of 41 , and combinations with stems other than the infinitive stem, namely (participle/-en), possess a type frequency of 144 .

If, for some reason, the system were to construct a participle formation from the stem and affix constituents, the most frequent stem werf, together with the most frequent participle suffix - $t$, and the most frequent combination type (infinitive/- $t$ ) would yield the combination gewerft, which corresponds to the default combination as suggested by a dual mechanism model (e.g. Clahsen, 1999; Pinker, 1999). The present model thus can explain the emergence of a 'default' form by postulating a learning algorithm instead of an inborn default mechanism.

\section{The frequency of combinations}

The link between a particular stem and a certain affix is strengthened by the frequency of their joint use. The 
surface frequency of a form reflects how often a particular stem-affix combination occurs, that is, it reflects the strength of the connections between these constituents. The model predicts that the more a specific combination is applied - as expressed by its surface frequency - the stronger the connection between its constituents, and the faster the responses for word decisions. Similarly, the model defines nonword decisions for illegal combination participles by the strength of existing stem-affix connections: Both correct and illegal combinations activate the same core meanings at the concept level. When the orthographic codes of gekauft and gekäuft are encountered, their constituent morphemes, ge-, kauf, $k \ddot{a} u f$, and $-t$ are accessed at the morpheme level. Both stems kauf and käuf equally activate the concept buy, and the affixes ge- and - $t$ activate the concept past. However, they differ in the amount of activation that is produced by the links between the constituents. The existing connections between kauf and - $t$ of the correct combination are strongly interconnected and thus boost the overall activation at the concept level. In contrast, there are no such connections for the illegally combined constituents $k \ddot{a} u f$ and $-t$, since $k \ddot{u} u f$ is usually combined with suffixes -lich and -er. Without existing and fostering links, the constituents of an illegal combination do not enhance the overall activation.

Furthermore, correct combinations differ from illegal combinations in the amount of activation that is fed back from the concept level. Feedback from the concept level always occurs for the strongest connections related to a concept, that is, for those constituents that are frequently used with it. For example, the concepts buy and past feed back to the morpheme level via the strongest links that are related to the joint concept bought, that is, to the morphemes ge-, kauf, and -t. For a correct participle this feedback will fasten a word response. In contrast, this feedback will yield conflicting information for an illegal combination, because the constituents that yield the most activation from the concept's feedback are different to those that actually activated these concepts. This feedback to different constituents at the morpheme level will cause a delay in responses. Indeed, illegal combination participles such as gekäuft or gekaufen were found to interfere with lexical decision latencies and accuracies relative to form-related pseudostem participles such as gekaust (Smolka, 2005).

In total, both the activation of links between existing constituents and feedback from the concept level to familiar morpheme connections will provide stronger overall activation for existing combinations than for nonexistent combinations. Finally, a nonword response may be reached for those constituents that trigger less activation in the system, namely illegal combinations. When the connections between correct stem and affixes are strong, this may add more to the overall activation, causing a relevant difference in the activation level produced by correct and incorrect combinations. However, when the connections are weak as with low-frequency participles, these weak connections between the correct stem-affix constituents will add little to the overall activation, and the feedback from the concept level to the correct constituents will be also relatively weak. Thus, incorrectly combined constituents will represent convincing competitors, making it more difficult to reject illegal combinations as nonwords. Smolka (2005) showed that the surface frequency, that is, the frequency of a correct stem-affix combination influences the decision process to classify an illegal combination as nonword: When the correct participle was of high frequency, decisions to reject an illegal stem-affix combination as nonword were faster than when the correct participle was of low frequency.

\section{Stem frequency versus surface frequency}

Previous models took the existence of stem frequency effects and surface frequency effects as a diagnostic for different processing stages or different processing routes: Decomposition models (Taft, 1979, 2004) interpreted the interaction between stem frequency and surface frequency as indicating two different stages of the word recognition process: Stem (i.e. base) frequency effects emerge at an early stage of processing when stems are accessed. Surface frequency effects arise at a later stage of processing, when the combinability of an accessed stem and an accessed affix is checked.

Dual route models assume the parallel activation of a parsing process and the retrieval of whole words (Baayen et al., 1997; Bertram et al., 2000; Niswander et al., 2000; Schreuder \& Baayen, 1995). Base frequency effects were interpreted to indicate that parsing was used, while surface frequency effects implied whole word retrieval.

In contrast to both types of models, the present model assumes that stem frequency and surface frequency effects arise simultaneously at the morpheme level: The frequency of the constituents affects the speed and strength with which the corresponding concepts are activated. The surface frequency, that is, the strength of the link between the constituents, supports the activation of these concepts in case of a word, or conflicts with the concept activation in case of nonwords. Thus, for high-frequency words the links between the constituents are particularly strong, so that they may override the effect of the single constituent, whereas the links between constituents are relatively weak for low-frequency words, so that a single stem will be more effective.

Thus, the assumption that base and surface frequency effects arise simultaneously makes the 
requirement for assuming two different processing routes (parsing vs. retrieval) or two different processing stages (early vs. late) superfluous. Therefore, morphemic constituents suffice as access representations to a concept without the explicit representation of whole words, since inflected (or otherwise complex) words are represented by their morphemic constituents, the links between these constituents, and the strength of these links.

\section{Acquisition, learning, and cross-language differences}

The model agrees with neural network models that stress the learning principles of the system (e.g., Plaut \& Gonnerman, 2000; Westermann, 2000, 2005). The frequency of specific stem-affix combinations encountered during language acquisition and language use determines which combinations are applied. That is, the system is flexible: Experience changes the weights of the connections between constituents. The system is able to adapt to shifts in language use (as the parallel use of irregular and regularized participle formations demonstrate) as well as to experimental conditions: In a lexical decision task, the use of nonwords comprising inflected pseudostems will stress the weight of the morphemic constituents, whereas the inclusion of nonwords comprising illegal combinations of existing stems with existing affixes will emphasize the connections between the constituents. The former type of nonwords should yield a base frequency effect, whereas illegal combinations should yield a surface frequency effect accompanied with a weakened or reversed base frequency effect as described in Taft (2004).

Cross-language differences, in particular those between morphologically rich and poor languages, could be explained in a similar way, that is, by differences in the relative weighting that the sublevels receive. In a morphologically rich language, such as German (Arabic or Hebrew), the morphological relations predominate the meaning: a morpheme (or root in Semitic languages) immediately activates its core concept, independent of the affix or word pattern relations. Indeed, semantically opaque derivations like umkommen (perish) primed their base verb like kommen (come) to the same degree as did transparent derivations like mitkommen (come along; Smolka, Komlósi, \& Rösler, 2006).

In contrast, in English, only semantically transparent derivations (successful) primed their base form (success), whereas semantically opaque derivations that feed a different concept (successor) did not (e.g. Marslen-Wilson et al., 1994). In terms of the model, in morphologically poor languages, the single constituents of a complex word receive less weight than the links between the constituents (corresponding to the whole word), so that the activation via the combined constituents outweighs that of the single constituents. In case of a transparent word, the morphemic constituents and the connections between them will feed to the same concept, whereas in case of a semantically opaque word, different concepts will be activated, and the activation of the concept that is fed by the joint connections will surpass the activation of the concept fed by the single constituent.

\section{The production of morphologically complex words}

The model in Fig. 2 can be easily adapted to capture findings in the realm of speech production by starting at the concept level, which feeds information via the morphemic level to phonemic output. For example, Zwitserlood, Bölte, and Dohmes (2005) found that the naming of a picture representing Sonne (sun) was facilitated to the same degree by the presentation of an illegal combination, such as sonnös (corresponding to an English nonword 'sunnous') as it was by the existing derived word sonnig (sunny). Such findings cannot be explained by established production models (e.g., Levelt, Roelofs, \& Meyer, 1999) that assume different lemmas (corresponding to different stems in the present study) for each type of word category: sonn1 for adjectives, sonn2 for nouns, and sonn3 for verbs. In contrast, the present model assumes only one representation of a morpheme with the same stem sonn regardless of word category. Hence, as soon as the concept sun is activated, this activation spreads to all morphemes that relate to the same concept, so that morphemic units can be primed by existing words and nonwords.

\section{Summary and conclusions}

The model describes a single system for the processing of complex forms. The main processes and characteristics of the system are the following: Orthographic strings are decomposed into their constituent morphemes, namely stems and affixes. These are accessed and activated for meaning. Most important, stems are not marked for grammatical category, and several related stem (or morphemic) variants activate the same underlying concept. How often a stem occurs in language use (as reflected in its base frequency) influences the amount of activation that a stem receives. How often a particular stem and affix combination occurs in a language (as reflected in the surface frequency of a word) determines the connection strength between constituents. These processes occur for morphologically simple and complex forms regardless of whether they represent regular or irregular inflection, and existing or nonexistent formations. 


\section{Appendix A}

Regular and irregular verb targets and participle primes (PT) in Sonnenstuhl et al. (1999)

\begin{tabular}{|c|c|c|c|c|c|c|c|c|c|c|c|c|}
\hline Target & SF & $N$ & $\mathrm{NF}$ & Syl & $L$ & PT prime & $\mathrm{PF}$ & $\mathrm{LF}$ & $N$ & NF & Syl & $L$ \\
\hline \multicolumn{13}{|c|}{ Regular verbs } \\
\hline leite & 0 & 23 & 5360 & 2 & 5 & geleitet & 11 & 71 & 5 & 7 & 3 & 8 \\
\hline packe & 0 & 29 & 48 & 2 & 5 & gepackt & 7 & 32 & 10 & 30 & 2 & 7 \\
\hline plane & 0 & 7 & 510 & 2 & 5 & geplant & 35 & 64 & 1 & 10 & 2 & 7 \\
\hline starte & 0 & 14 & 499 & 2 & 6 & gestartet & 15 & 51 & 2 & 215 & 3 & 9 \\
\hline kriege & 1 & 4 & 362 & 2 & 6 & gekriegt & 4 & 37 & 0 & 0 & 2 & 8 \\
\hline lerne & 1 & 10 & 521 & 2 & 5 & gelernt & 30 & 121 & 2 & 14 & 2 & 7 \\
\hline öffne & 1 & 0 & 0 & 2 & 5 & geöffnet & 34 & 104 & 0 & 0 & 3 & 8 \\
\hline ordne & 1 & 0 & 0 & 2 & 5 & geordnet & 7 & 24 & 0 & 0 & 3 & 8 \\
\hline segne & 1 & 10 & 7765 & 2 & 5 & gesegnet & 2 & 4 & 1 & 2 & 3 & 8 \\
\hline stürze & 1 & 9 & 133 & 2 & 6 & gestürzt & 11 & 59 & 4 & 141 & 2 & 8 \\
\hline kaufe & 2 & 13 & 468 & 2 & 5 & gekauft & 20 & 124 & 2 & 19 & 2 & 7 \\
\hline prüfe & 2 & 2 & 48 & 2 & 5 & geprüft & 22 & 77 & 0 & 0 & 2 & 7 \\
\hline warne & 2 & 12 & 227 & 2 & 5 & gewarnt & 13 & 58 & 2 & 20 & 2 & 7 \\
\hline weine & 2 & 37 & 18340 & 2 & 5 & geweint & 5 & 50 & 6 & 305 & 2 & 7 \\
\hline herrsche & 3 & 1 & 198 & 2 & 8 & geherrscht & 2 & 69 & 1 & 118 & 2 & 10 \\
\hline leiste & 3 & 10 & 189 & 2 & 6 & geleistet & 34 & 151 & 0 & 0 & 3 & 9 \\
\hline folge & 4 & 5 & 909 & 2 & 5 & gefolgt & 17 & 190 & 3 & 61 & 2 & 7 \\
\hline handle & 7 & 2 & 2 & 2 & 6 & gehandelt & 24 & 222 & 4 & 379 & 3 & 9 \\
\hline rechne & 8 & 3 & 517 & 2 & 6 & gerechnet & 41 & 179 & 1 & 55 & 3 & 9 \\
\hline zeige & 12 & 16 & 1177 & 2 & 5 & gezeigt & 78 & 528 & 3 & 80 & 2 & 7 \\
\hline hoffe & 26 & 2 & 142 & 2 & 5 & gehofft & 6 & 112 & 0 & 0 & 2 & 7 \\
\hline Mean & 3.7 & 10.0 & 1781.7 & 2.0 & 5.4 & & 19.9 & 110.8 & 2.2 & 69.3 & 2.4 & 7.8 \\
\hline \multicolumn{13}{|c|}{ Irregular verbs } \\
\hline blase & 0 & 8 & 115 & 2 & 5 & geblasen & 2 & 14 & 2 & 0 & 3 & 8 \\
\hline brate & 0 & 6 & 29 & 2 & 5 & gebraten & 1 & 2 & 0 & 0 & 3 & 8 \\
\hline fresse & 0 & 5 & 534 & 2 & 6 & gefressen & 3 & 17 & 0 & 0 & 3 & 9 \\
\hline grabe & 0 & 17 & 348 & 2 & 5 & gegraben & 2 & 9 & 1 & 74 & 3 & 8 \\
\hline lade & 1 & 17 & 1792 & 2 & 4 & geladen & 12 & 45 & 4 & 62 & 3 & 7 \\
\hline messe & 1 & 7 & 1260 & 2 & 5 & gemessen & 22 & 49 & 3 & 120 & 3 & 8 \\
\hline wasche & 1 & 12 & 302 & 2 & 6 & gewaschen & 6 & 20 & 0 & 0 & 3 & 9 \\
\hline esse & 2 & 5 & 11 & 2 & 4 & gegessen & 7 & 67 & 4 & 197 & 3 & 8 \\
\hline fange & 2 & 19 & 1762 & 2 & 5 & gefangen & 11 & 72 & 6 & 686 & 3 & 8 \\
\hline rate & 2 & 17 & 308 & 2 & 4 & geraten & 23 & 42 & 7 & 477 & 3 & 7 \\
\hline schlafe & 2 & 8 & 92 & 2 & 7 & geschlafen & 7 & 67 & 2 & 200 & 3 & 10 \\
\hline stoße & 2 & 3 & 11 & 2 & 5 & gestoßen & 14 & 101 & 1 & 0 & 3 & 8 \\
\hline trete & 3 & 3 & 121 & 2 & 5 & getreten & 30 & 283 & 2 & 76 & 3 & 8 \\
\hline laufe & 4 & 20 & 444 & 2 & 5 & gelaufen & 15 & 217 & 2 & 23 & 3 & 8 \\
\hline schlage & 4 & 8 & 99 & 2 & 7 & geschlagen & 33 & 224 & 2 & 50 & 3 & 10 \\
\hline lese & 6 & 8 & 217 & 2 & 4 & gelesen & 33 & 159 & 6 & 2332 & 3 & 7 \\
\hline rufe & 6 & 11 & 644 & 2 & 4 & gerufen & 16 & 156 & 3 & 198 & 3 & 7 \\
\hline lasse & 13 & 22 & 696 & 2 & 5 & gelassen & 18 & 937 & 2 & 40 & 3 & 8 \\
\hline halte & 45 & 25 & 11913 & 2 & 5 & gehalten & 76 & 667 & 5 & 233 & 3 & 8 \\
\hline gebe & 50 & 12 & 566 & 2 & 4 & gegeben & 199 & 1729 & 2 & 70 & 3 & 7 \\
\hline sehe & 58 & 12 & 6230 & 2 & 4 & gesehen & 154 & 1174 & 1 & 16 & 3 & 7 \\
\hline Mean & 9.6 & 11.7 & 1309.2 & 2.0 & 5.0 & & 32.6 & 288.1 & 2.6 & 231.1 & 3.0 & 8.0 \\
\hline
\end{tabular}

Note. SF, surface frequency; $N$, number of neighbors; NF, neighborhood frequency; Syl, number of syllables; $L$, number of letters; PF, participle frequency, LF, lemma frequency. 


\section{Appendix B}

Regular and Irregular Verb Targets and Their Corresponding Participle (PT), Unrelated Participle (UPT), Illegal Combination Participle (ICP), and Pseudostem Participle (PSP) as Primes

\begin{tabular}{|c|c|c|c|c|c|c|c|c|c|c|c|c|c|c|c|c|c|}
\hline Target & IF & PT & PF & $\mathbf{L F}$ & $\mathbf{N}$ & $\mathbf{L}$ & UPT & PF & $\mathbf{L F}$ & $\mathbf{N}$ & $\mathbf{L}$ & $\begin{array}{c}\text { ICP } \\
\text { nonverbal }\end{array}$ & $\mathbf{N}$ & $\mathbf{L}$ & PSP & $\mathbf{N}$ & $\mathbf{L}$ \\
\hline \multicolumn{18}{|c|}{ Regular Verbs } \\
\hline duften & 0 & geduftet & 0 & 4 & 0 & 8 & gefaselt & 0 & 1 & 3 & 8 & gedüftet & 2 & 8 & gedustet & 3 & 8 \\
\hline häuten & 0 & gehäutet & 0 & 1 & 2 & 8 & gedampft & 0 & 3 & 3 & 8 & gehautet & 5 & 8 & gehäunet & 1 & 8 \\
\hline morden & 0 & gemordet & 1 & 2 & 0 & 8 & gefaltet & 1 & 4 & 3 & 8 & gemördet & 1 & 8 & gemorket & 1 & 8 \\
\hline nächtigen & 0 & genächtigt & 0 & 1 & 0 & 10 & geplatscht & 0 & 0 & 2 & 10 & genachtigt & 1 & 10 & genächsigt & 1 & 10 \\
\hline näseln & 0 & genäselt & 0 & 0 & 1 & 8 & gelauert & 0 & 7 & 6 & 8 & genaselt & 5 & 8 & genäfelt & 2 & 8 \\
\hline pfänden & 0 & gepfändet & 0 & 1 & 0 & 9 & gemanscht & 0 & 0 & 2 & 9 & gepfandet & 1 & 9 & gepfänset & 1 & 9 \\
\hline säuern & 0 & gesäuert & 0 & 0 & 0 & 8 & gehadert & 0 & 1 & 2 & 8 & gesauert & 5 & 8 & gesänert & 1 & 8 \\
\hline schlängeln & 0 & geschlängelt & 0 & 1 & 0 & 12 & geratschlagt & 0 & 0 & 1 & 12 & geschlangelt & 1 & 12 & geschläugelt & 1 & 12 \\
\hline schwärzen & 0 & geschwärzt & 0 & 2 & 3 & 10 & geträllert & 0 & 1 & 1 & 10 & geschwarzt & 2 & 10 & geschwärpt & 2 & 10 \\
\hline stranden & 0 & gestrandet & 0 & 1 & 0 & 10 & geräuchert & 0 & 1 & 0 & 10 & gesträndet & 1 & 10 & gestraudet & 1 & 10 \\
\hline wurmen & 0 & gewurmt & 0 & 1 & 1 & 7 & gemurrt & 0 & 2 & 2 & 7 & gewürmt & 5 & 7 & gewurbt & 1 & 7 \\
\hline schärfen & 1 & geschärft & 1 & 3 & 1 & 9 & geforscht & 1 & 7 & 0 & 9 & gescharft & 3 & 9 & geschärmt & 3 & 9 \\
\hline schäumen & 1 & geschäumt & 0 & 2 & 1 & 9 & gegackert & 0 & 0 & 2 & 9 & geschaumt & 2 & 9 & geschäust & 2 & 9 \\
\hline schwärmen & 1 & geschwärmt & 0 & 7 & 1 & 10 & geglitzert & 0 & 3 & 0 & 10 & geschwarmt & 1 & 10 & geschwärkt & 2 & 10 \\
\hline spotten & 1 & gespottet & 0 & 5 & 1 & 9 & gelauscht & 0 & 10 & 4 & 9 & gespöttet & 2 & 9 & gespostet & 1 & 9 \\
\hline türmen & 1 & getürmt & 0 & 4 & 0 & 7 & gezapft & 1 & 1 & 1 & 7 & geturmt & 3 & 7 & getülmt & 1 & 7 \\
\hline wüten & 1 & gewütet & 0 & 23 & 2 & 7 & gehehlt & 0 & 0 & 4 & 7 & gewutet & 5 & 7 & gewüset & 1 & 7 \\
\hline zähmen & 1 & gezähmt & 0 & 2 & 5 & 7 & gehallt & 0 & 3 & 4 & 7 & gezahmt & 5 & 7 & gezähst & 3 & 7 \\
\hline glänzen & 2 & geglänzt & 0 & 17 & 0 & 8 & getuscht & 0 & 0 & 6 & 8 & geglanzt & 1 & 8 & gegläuzt & 1 & 8 \\
\hline züchten & 2 & gezüchtet & 1 & 4 & 2 & 9 & gezaubert & 1 & 5 & 2 & 9 & gezuchtet & 3 & 9 & gezüchset & 1 & 9 \\
\hline kauen & 3 & gekaut & 0 & 7 & 3 & 6 & geaalt & 0 & 0 & 4 & 6 & gekäut & 3 & 6 & gekaft & 2 & 6 \\
\hline büßen & 4 & gebüßt & 0 & 10 & 2 & 6 & gedöst & 0 & 1 & 1 & 6 & gebußt & 6 & 6 & gebümt & 1 & 6 \\
\hline schmücken & 0 & geschmückt & 4 & 9 & 1 & 10 & geschwächt & 4 & 17 & 0 & 10 & geschmuckt & 3 & 10 & geschmücht & 1 & 10 \\
\hline fälschen & 1 & gefälscht & 2 & 4 & 0 & 9 & gezündet & 2 & 11 & 1 & 8 & gefalscht & 1 & 9 & gefänscht & 1 & 9 \\
\hline faulen & 1 & gefault & 0 & 3 & 3 & 7 & geruckt & 0 & 2 & 10 & 7 & gefäult & 2 & 7 & gefaugt & 4 & 7 \\
\hline hämmern & 1 & gehämmert & 1 & 5 & 3 & 9 & gewässert & 1 & 1 & 4 & 9 & gehammert & 2 & 9 & gehämsert & 1 & 9 \\
\hline nageln & 1 & genagelt & 1 & 3 & 3 & 8 & gezankt & 1 & 3 & 7 & 7 & genägelt & 2 & 8 & genakelt & 5 & 8 \\
\hline strafen & 1 & gestraft & 2 & 4 & 1 & 8 & gebucht & 2 & 5 & 1 & 7 & gesträft & 1 & 8 & gestragt & 1 & 8 \\
\hline brüten & 2 & gebrütet & 0 & 4 & 1 & 8 & gepinnt & 0 & 0 & 5 & 7 & gebrutet & 2 & 8 & gebrüset & 1 & 8 \\
\hline säubern & 2 & gesäubert & 1 & 5 & 1 & 9 & gesättigt & 1 & 1 & 0 & 9 & gesaubert & 3 & 9 & gesäunert & 1 & 9 \\
\hline färben & 3 & gefärbt & 4 & 9 & 0 & 7 & gebückt & 4 & 9 & 3 & 7 & gefarbt & 3 & 7 & gefärkt & 2 & 7 \\
\hline stürmen & 3 & gestürmt & 1 & 14 & 4 & 8 & gemästet & 1 & 2 & 2 & 8 & gesturmt & 1 & 8 & gestürgt & 2 & 8 \\
\hline schämen & 5 & geschämt & 1 & 16 & 3 & 8 & geknackt & 1 & 4 & 3 & 8 & geschamt & 5 & 8 & geschäbt & 4 & 8 \\
\hline häufen & 6 & gehäuft & 1 & 11 & 0 & 7 & geklagt & 1 & 28 & 3 & 7 & gehauft & 5 & 7 & gehäugt & 3 & 7 \\
\hline träumen & 7 & geträumt & 4 & 26 & 0 & 8 & gekränkt & 4 & 8 & 3 & 8 & getraumt & 3 & 8 & geträust & 3 & 8 \\
\hline gründen & 13 & gegründet & 30 & 62 & 1 & 9 & geändert & 39 & 111 & 0 & 8 & gegrundet & 1 & 9 & gegrünset & 1 & 9 \\
\hline tanzen & 13 & getanzt & 4 & 32 & 3 & 7 & geahnt & 4 & 32 & 1 & 6 & getänzt & 1 & 7 & getangt & 7 & 7 \\
\hline fürchten & 19 & gefürchtet & 4 & 58 & 1 & 10 & geschädigt & 4 & 8 & 1 & 10 & gefurchtet & 1 & 10 & gefüschtet & 1 & 10 \\
\hline wünschen & 39 & gewünscht & 14 & 116 & 0 & 9 & geschätzt & 16 & 53 & 1 & 9 & gewunscht & 1 & 9 & gewüpscht & 1 & 9 \\
\hline wählen & 42 & gewählt & 62 & 136 & 3 & 7 & gezeigt & 78 & 528 & 3 & 7 & gewahlt & 5 & 7 & gewähst & 2 & 7 \\
\hline bauen & 44 & gebaut & 52 & 139 & 4 & 6 & gefordert & 63 & 278 & 1 & 9 & gebäut & 4 & 6 & gebant & 2 & 6 \\
\hline handeln & 47 & gehandelt & 24 & 222 & 4 & 9 & getrennt & 25 & 65 & 1 & 8 & gehändelt & 4 & 9 & gehanselt & 2 & 9 \\
\hline kämpfen & 49 & gekämpft & 10 & 104 & 2 & 8 & gezählt & 10 & 85 & 4 & 7 & gekampft & 3 & 8 & gekumpft & 1 & 8 \\
\hline kaufen & 67 & gekauft & 20 & 124 & 2 & 7 & geprüft & 22 & 77 & 0 & 7 & gekäuft & 2 & 7 & gekaust & 8 & 7 \\
\hline Mean & 8,7 & & 5,6 & 27,4 & 1,5 & 8,3 & & 6,5 & 31,1 & 2,4 & 8,1 & & 2,7 & 8,3 & & 2,0 & 8,3 \\
\hline
\end{tabular}

Irregular Verbs

$\begin{array}{ll}\text { bersten } & 0 \\ \text { kneifen } & 0 \\ \text { schlingen } & 0 \\ \text { spinnen } & 0 \\ \text { dreschen } & 1 \\ \text { sprießen } & 1 \\ \text { saufen } & 1 \\ \text { schelten } & 1 \\ \text { schmeißen } & 1 \\ \text { schleifen } & 1 \\ \text { stinken } & 2 \\ \text { reiben } & 2 \\ \text { schleichen } & 2 \\ \text { schmelzen } & 2 \\ \text { stechen } & 2 \\ \text { leihen } & 2 \\ \text { kriechen } & 3 \\ \text { meiden } & 3 \\ \text { gleiten } & 5\end{array}$

$\begin{array}{lllll}\text { geborsten } & 0 & 2 & 0 & 9 \\ \text { gekniffen } & 0 & 3 & 0 & 9 \\ \text { geschlungen } & 1 & 5 & 1 & 1 \\ \text { gesponnen } & 1 & 6 & 1 & 9 \\ \text { gedroschen } & 0 & 2 & 0 & 10 \\ \text { gesprossen } & 0 & 2 & 0 & 10 \\ \text { gesoffen } & 1 & 3 & 1 & 8 \\ \text { gescholten } & 1 & 5 & 1 & 10 \\ \text { geschmissen } & 1 & 4 & 2 & 1 \\ \text { geschliffen } & 2 & 4 & 0 & 1 \\ \text { gestunken } & 0 & 7 & 0 & 9 \\ \text { gerieben } & 1 & 13 & 1 & 8 \\ \text { geschlichen } & 1 & 16 & 1 & 1 \\ \text { geschmolzen } & 1 & 8 & 0 & 1 \\ \text { gestochen } & 1 & 12 & 1 & 9 \\ \text { geliehen } & 2 & 7 & 4 & 8 \\ \text { gekrochen } & 1 & 12 & 2 & 9 \\ \text { gemieden } & 1 & 7 & 0 & 8 \\ \text { geglitten } & 0 & 17 & 0 & 9\end{array}$

ICP verbal

geborste

$\begin{array}{llllllll}\text { gewrungen } & 0 & 1 & 2 & 9 & \text { geborstet } & 3 & 9 \\ \text { geronnen } & 0 & 3 & 6 & 8 & \text { geknifft } & 0 & 8 \\ \text { geschrocken } & 0 & 3 & 0 & 11 & \text { geschlungt } & 0 & 10 \\ \text { gepriesen } & 1 & 6 & 0 & 9 & \text { gesponnt } & 2 & 8 \\ \text { geschienen } & 0 & 344 & 2 & 10 & \text { gedroscht } & 0 & 9 \\ \text { geschnoben } & 0 & 3 & 0 & 10 & \text { gesprosst } & 0 & 9 \\ \text { gesonnen } & 1 & 5 & 3 & 8 & \text { gesofft } & 2 & 7 \\ \text { geschrien } & 0 & 72 & 1 & 9 & \text { gescholtet } & 2 & 10 \\ \text { geschieden } & 9 & 30 & 2 & 10 & \text { geschmisst } & 0 & 10 \\ \text { geschwollen } & 2 & 5 & 0 & 11 & \text { geschlifft } & 0 & 10 \\ \text { gepflogen } & 0 & 16 & 0 & 9 & \text { gestunkt } & 0 & 8 \\ \text { gewichen } & 2 & 22 & 0 & 8 & \text { geriebt } & 4 & 7 \\ \text { geschunden } & 1 & 1 & 0 & 10 & \text { geschlicht } & 3 & 10 \\ \text { geschissen } & 0 & 0 & 2 & 10 & \text { geschmolzt } & 3 & 10 \\ \text { geschoren } & 1 & 2 & 1 & 9 & \text { gestocht } & 1 & 8 \\ \text { gerungen } & 2 & 16 & 5 & 8 & \text { gelieht } & 5 & 7 \\ \text { geworben } & 3 & 18 & 4 & 8 & \text { gekrocht } & 2 & 8 \\ \text { gemolken } & 1 & 3 & 0 & 8 & \text { gemiedet } & 3 & 8 \\ \text { geklommen } & 0 & 0 & 2 & 9 & \text { geglittet } & 1 & 9\end{array}$

$\begin{array}{lll}\text { gebelsten } & 0 & 9 \\ \text { gekneisen } & 0 & 9 \\ \text { geschlinzen } & 0 & 11 \\ \text { gespingen } & 0 & 9 \\ \text { gedreuchen } & 0 & 10 \\ \text { gespriefen } & 0 & 10 \\ \text { gesaulen } & 0 & 8 \\ \text { geschelnen } & 0 & 10 \\ \text { geschmeiken } & 1 & 11 \\ \text { geschleigen } & 0 & 11 \\ \text { gestinsen } & 0 & 9 \\ \text { gereilen } & 0 & 8 \\ \text { geschleicken } & 0 & 12 \\ \text { geschmelfen } & 0 & 11 \\ \text { gestuchen } & 1 & 9 \\ \text { geleifen } & 3 & 8 \\ \text { gekriecken } & 0 & 10 \\ \text { gemeiren } & 1 & 8 \\ \text { gegleifen } & 0 & 9\end{array}$


Appendix B (continued)

\begin{tabular}{|c|c|c|c|c|c|c|c|c|c|c|c|c|c|c|c|c|c|}
\hline Target & IF & PT & PF & $\mathbf{L F}$ & $\mathbf{N}$ & $\mathbf{L}$ & UPT & PF & $\mathbf{L F}$ & $\mathbf{N}$ & $\mathbf{L}$ & $\begin{array}{c}\text { ICP } \\
\text { verbal }\end{array}$ & $\mathbf{N}$ & $\mathbf{L}$ & PSP & $\mathbf{N}$ & $\mathbf{L}$ \\
\hline pfeifen & 5 & gepfiffen & 1 & 21 & 0 & 9 & gewunden & 1 & 6 & 6 & 8 & gepfifft & 0 & 8 & gepfeisen & 0 & 9 \\
\hline schwimmen & 19 & geschwommen & 2 & 26 & 0 & 11 & geschritten & 2 & 24 & 2 & 11 & geschwommt & 1 & 10 & geschwimsen & 0 & 11 \\
\hline \multirow[t]{2}{*}{ streiten } & 13 & gestritten & 2 & 21 & 1 & 10 & gesotten & 0 & 0 & 0 & 8 & gestrittet & 2 & 10 & gestreimen & 0 & 10 \\
\hline & & & & & & & & & & & & $\begin{array}{l}\text { ICP } \\
\text { nonverbal }\end{array}$ & & & & & \\
\hline quellen & 0 & gequollen & 0 & 3 & 0 & 9 & gefochten & 0 & 3 & 1 & 9 & gequallt & 2 & 8 & gequelst & 1 & 8 \\
\hline gießen & 0 & gegossen & 2 & 11 & 4 & 8 & geritten & 3 & 22 & 3 & 8 & gegusst & 0 & 7 & gegient & 2 & 7 \\
\hline trügen & 1 & getrogen & 0 & 3 & 2 & 8 & gebacken & 0 & 0 & 1 & 8 & getrugt & 2 & 7 & getrünt & 3 & 7 \\
\hline biegen & 1 & gebogen & 1 & 10 & 7 & 7 & gebraten & 1 & 2 & 0 & 8 & gebugt & 4 & 6 & gebiezt & 2 & 7 \\
\hline weben & 1 & gewoben & 1 & 3 & 4 & 7 & gehauen & 1 & 9 & 3 & 7 & gewabt & 5 & 6 & geweft & 2 & 6 \\
\hline schwinden & 2 & geschwunden & 1 & 6 & 2 & 11 & geflochten & 1 & 3 & 1 & 10 & geschwündet & 1 & 11 & geschwinset & 0 & 11 \\
\hline schwören & 2 & geschworen & 3 & 11 & 2 & 10 & gefressen & 3 & 17 & 0 & 9 & geschwurt & 1 & 9 & geschwogt & 0 & 9 \\
\hline riechen & 3 & gerochen & 1 & 23 & 2 & 8 & gegraben & 2 & 9 & 1 & 8 & gerucht & 9 & 7 & gerieckt & 0 & 8 \\
\hline schwingen & 3 & geschwungen & 1 & 19 & 2 & 11 & geklungen & 2 & 55 & 0 & 9 & geschwüngt & 0 & 10 & geschwinnt & 0 & 10 \\
\hline wiegen & 3 & gewogen & 1 & 10 & 7 & 7 & gekoren & 0 & 1 & 3 & 7 & gewaagt & 0 & 7 & gewiebt & 3 & 7 \\
\hline fließen & 8 & geflossen & 2 & 32 & 0 & 9 & geblasen & 2 & 14 & 2 & 8 & geflusst & 0 & 8 & geflient & 1 & 8 \\
\hline schieben & 8 & geschoben & 9 & 62 & 1 & 9 & gesessen & 9 & 248 & 3 & 8 & geschubt & 2 & 8 & geschiezt & 4 & 9 \\
\hline binden & 10 & gebunden & 33 & 58 & 4 & 8 & gefahren & 38 & 485 & 4 & 8 & gebündet & 2 & 8 & gebinget & 0 & 8 \\
\hline springen & 13 & gesprungen & 3 & 74 & 1 & 10 & gedrungen & 3 & 78 & 2 & 9 & gesprüngt & 1 & 9 & gesprinst & 0 & 9 \\
\hline heben & 18 & gehoben & 4 & 115 & 4 & 7 & gelogen & 5 & 16 & 8 & 7 & gehubt & 4 & 6 & geheßt & 6 & 6 \\
\hline brechen & 18 & gebrochen & 7 & 61 & 2 & 9 & geschlafen & 7 & 67 & 2 & 10 & gebrucht & 2 & 8 & gebreckt & 3 & 8 \\
\hline schießen & 22 & geschossen & 16 & 75 & 4 & 10 & gewaschen & 20 & 20 & 0 & 9 & geschusst & 2 & 9 & geschiegt & 4 & 9 \\
\hline werfen & 29 & geworfen & 19 & 152 & 3 & 8 & geholfen & 19 & 206 & 2 & 8 & gewurft & 3 & 7 & gewenft & 0 & 7 \\
\hline fliegen & 43 & geflogen & 13 & 106 & 2 & 8 & geboten & 15 & 194 & 8 & 7 & geflugt & 0 & 7 & gefliebt & 1 & 8 \\
\hline ziehen & 47 & gezogen & 51 & 284 & 5 & 7 & gegangen & 73 & 1227 & 4 & 8 & gezugt & 3 & 6 & gezient & 5 & 7 \\
\hline schließen & 51 & geschlossen & 61 & 212 & 2 & 11 & geschrieben & 67 & 306 & 1 & 11 & geschlusst & 0 & 10 & geschlient & 0 & 10 \\
\hline gelten & 65 & gegolten & 3 & 320 & 0 & 8 & geheißen & 3 & 215 & 2 & 8 & gegültet & 0 & 8 & gegentet & 0 & 8 \\
\hline Mean & 9,2 & & 5,7 & 42,1 & 1,7 & 9,1 & & 6,8 & 85,8 & 2,0 & 8,8 & & 1,8 & 8,3 & & 1,0 & 8,8 \\
\hline
\end{tabular}

Note. $\mathrm{IF}=$ Infinitive Frequency, $\mathrm{PF}=$ Participle Frequency, $\mathrm{LF}=$ Lemma Frequency, $\mathrm{N}=$ Number of Neighbors, $\mathrm{L}=\mathrm{Number}$ of Letters

\section{References}

Arduino, L. S., \& Burani, C. (2004). Neighborhood effects on nonword visual processing in a language with shallow orthography. Journal of Psycholinguistic Research, 33, 75-95.

Baayen, R. H., Dijkstra, T., \& Schreuder, R. (1997). Singulars and plurals in Dutch: Evidence for a parallel dual-route model. Journal of Memory and Language, 37, 94-117.

Baayen, R., Piepenbrock, R., \& Van Rijn, H. (1993). The CELEX lexical database (on CD-ROM). Philadelphia, PA: Linguistic Data Consortium, University of Pennsylvania.

Beedham, C. (1994). The role of consonants in marking strong verb conjugation in German and English. Folia Linguistica, 28, 279-296.

Bertram, R., Schreuder, R., \& Baayen, H. (2000). The role of context in morphological processing: Evidence from Finnish. Language and Cognitive Processes, 15, 367-388.

Burani, C., \& Caramazza, A. (1987). Representation and processing in derived words. Language and Cognitive Processes, 2, 217-227.

Butterworth, B. (1983). Lexical representation. In B. Butterworth (Ed.), Language production: Development, writing and other language processes (Vol. 2, pp. 257-294). London: Academic Press.

Caramazza, A., Laudanna, A., \& Romani, C. (1988). Lexical access and inflectional morphology. Cognition, 28, 297-332.

Chialant, D., \& Caramazza, A. (1995). Where is morphology and how is it processed? The case of written word recognition. In L. B. Feldman (Ed.), Morphological aspects of language processing (pp. 55-76). Hillsdale, NJ: Erlbaum.
Chomsky, N., \& Halle, M. (1968). The sound pattern of English. New York: Harper \& Row.

Clahsen, H. (1999). Lexical entries and rules of language: A multidisciplinary study of German inflection. Behavioral and Brain Sciences, 22, 991-1060.

Clahsen, H., Eisenbeiss, S., Hadler, M., \& Sonnenstuhl, I. (2001). The mental representation of inflected words: An experimental study of adjectives and verbs in German. Language, 77, 510-543.

Clahsen, H., Eisenbeiss, S., \& Sonnenstuhl-Henning, I. (1997). Morphological structure and the processing of inflected words. Theoretical Linguistics, 23, 201-249.

Clahsen, H., Prüfert, P., Eisenbeiss, S., \& Cholin, J. (2002). Strong stems in the German mental lexicon: Evidence from child language acquisition and adult processing. In I. Kaufmann \& B. Stiebels (Eds.), More than words. A Festschrift for Dieter Wunderlich (pp. 91-112). Berlin: Akadamie Verlag.

Colé, P., Segui, J., \& Taft, M. (1997). Words and morphemes as units for lexical access. Journal of Memory and Language, 37, 312-330.

Deutsch, A., Frost, R., \& Forster, K. I. (1998). Verbs and nouns are organized and accessed differently in the mental lexicon: Evidence from Hebrew. Journal of Experimental Psychology: Learning, Memory, and Cognition, 24, 1238-1255.

Digital Wenker-Atlas (2005). http://www.diwa.info/ (July 2005).

Drews, E. (1999). Pitfalls in tracking the psychological reality of lexically based and rule-based inflection. Behavioral and Brain Sciences, 22, 1022. 
Drews, E., \& Zwitserlood, P. (1995). Morphological and orthographic similarity in visual word recognition. Journal of Experimental Psychology: Human Perception and Performance, 21, 1098-1116.

Durrell, M. (2001). Strong verb ablaut in the West Germanic languages. In S. Watts, J. West, \& H. Solms (Eds.), Zur Verbmorphologie germanischer Sprachen (pp. 5-18). Tübingen: Max Niemeyer.

Forster, K. I., Davis, C., Schoknecht, C., \& Carter, R. (1987). Masked priming with graphemically related forms: Repetition or partial activation? The Quarterly Journal of Experimental Psychology, 39, 211-251.

Frost, R., Forster, K. I., \& Deutsch, A. (1997). What can we learn from the morphology of Hebrew? A masked-priming investigation of morphological representation. Journal of Experimental Psychology: Learning, Memory, and Cognition, 23, 829-856.

Giraudo, H., \& Grainger, J. (2000). Effects of word frequency and cumulative root frequency in masked morphological priming. Language and Cognitive Processes, 15, 421-444.

Giraudo, H., \& Grainger, J. (2001). Priming complex words: Evidence for supralexical representation of morphology. Psychonomic Bulletin and Review, 8, 127-131.

Henderson, L., Wallis, J., \& Knight, D. (1984). Morphemic structure and lexical access. In H. Bouma \& D. G. Bouwhuis (Eds.), Attention and performance X: Control of language processes (pp. 211-226). Hillsdale, NJ: Erlbaum.

Levelt, W. J., Roelofs, A., \& Meyer, A. S. (1999). A theory of lexical access in speech production. Behavioral and Brain Sciences, 22, 1-75.

Longtin, C.-M., \& Meunier, F. (2005). Morphological decomposition in early visual word processing. Journal of Memory and Language, 53, 26-41.

Marcus, G. F., Brinkmann, U., Clahsen, H., Wiese, R., \& Pinker, S. (1995). German inflection: The exception that proves the rule. Cognitive Psychology, 29, 189-256.

Marslen-Wilson, W. (1999). Abstractness and combination: The morphemic lexicon. In S. Garrod \& M. J. Pickering (Eds.), Language processing (pp. 101-119). Hove: Psychology Press.

Marslen-Wilson, W., Tyler, L. K., Waksler, R., \& Older, L. (1994). Morphology and meaning in the English mental lexicon. Psychological Review, 101, 3-33.

Masson, M. E., \& Loftus, G. R. (2003). Using confidence intervals for graphically based data interpretation. Canadian Journal of Experimental Psychology, 57, 203-220.

Meunier, F., \& Marslen-Wilson, W. (2004). Regularity and irregularity in French verbal inflection. Language and Cognitive Processes, 19, 561-580.

Napps, S. E. (1989). Morphemic relationships in the lexicon: Are they distinct from semantic and formal relationships? Memory and Cognition, 17, 729-739.

Niswander, E., Pollatsek, A., \& Rayner, K. (2000). The processing of derived and inflected suffixed words during reading. Language and Cognitive Processes, 15, 389-420.

Orsolini, M., \& Marslen-Wilson, W. (1997). Universals in morphological representation: Evidence from Italian. Language and Cognitive Processes, 12, 1-47.

Pastizzo, M. J., \& Feldman, L. B. (2002). Discrepancies between orthographic and unrelated baselines in masked priming undermine a decompositional account of morpho- logical facilitation. Journal of Experimental Psychology: Learning, Memory, and Cognition, 28, 244-249.

Pinker, S. (1998). Rules of language. In P. Thagard (Ed.), Mind readings: Introductory selections on cognitive science (pp. 77-92). Cambridge, Mass: MIT Press.

Pinker, S. (1999). Words and rules. New York: Basic Books.

Pinker, S., \& Ullman, M. T. (2002). The past-tense debate. The past and future of the past tense. Trends in Cognitive Sciences, 6, 456-463.

Plaut, D. C., \& Gonnerman, L. M. (2000). Are non-semantic morphological effects incompatible with a distributed connectionist approach to lexical processing? Language and Cognitive Processes, 15, 445-485.

Prasada, S., \& Pinker, S. (1993). Generalization of regular and irregular morphological patterns. Language and Cognitive Processes, 8, 1-56.

Rastle, K., McCormick, S. \& Davis, M. H. (2005). Is there a 'fete' in 'fetish'? Effects of orthographic opacity on morphoorthographic segmentation in visual word recognition. Paper presented at the 5th International Morphology Workshop, Cambridge, UK.

Raveh, M. (2002). The contribution of frequency and semantic similarity to morphological processing. Brain and Language, $81,312-325$.

Rueckl, J. G., Mikolinski, M., Raveh, M., Miner, C. S., \& Mars, F. (1997). Morphological priming, fragment completion, and connectionist networks. Journal of Memory and Language, 36, 382-405.

Rueckl, J. G., \& Raveh, M. (1999). The influence of morphological regularities on the dynamics of a connectionist network. Brain and Language, 68, 110-117.

Schreuder, R., \& Baayen, R. H. (1995). Modeling morphological processing. In L. B. Feldman (Ed.), Morphological aspects of language processing (pp. 131-154). Hillsdale, NJ: Erlbaum.

Seidenberg, M. S., \& Arnoldussen, A. (2003). The brain makes a distinction between hard and easy stimuli: Comments on Beretta et al. Brain and Language, 85, 527-530.

Smith, P. T. (1995). Are morphemes really necessary? In L. B. Feldman (Ed.), Morphological aspects of language processing (pp. 365-382). Hillsdale, NJ: Erlbaum.

Smolka, E. (2005). The basic ingredients of lexical access and representation: Evidence from German participles. Unpublished doctoral dissertation, Philipps-University Marburg, Germany.

Smolka, E., Rösler, F., \& Wiese, R. (2003). Morphological and semantic priming effects in the processing of German verbs: Evidence from reaction times and event related potentials. In Bajo, T., \& Lupianez, J. (Eds.), Proceedings of the thirteenth conference of the European society for cognitive psychology. ESCoP 2003, Granada, Spain (p. 494). Imprenta Santa Rita: Monachil, Granada.

Smolka, E., Komlósi, S., \& Rösler, F. (2006, August). When semantics means less than morphology: The processing of German prefixed verbs. Paper presented at the 12th annual conference on architectures and mechanisms for language processing (AMLaP), Nijmegen, Netherlands.

Sonnenstuhl, I., Eisenbeiss, S., \& Clahsen, H. (1999). Morphological priming in the German mental lexicon. Cognition, 72, 203-236. 
Stanners, R. F., Neiser, J. J., Hernon, W. P., \& Hall, R. (1979). Memory representation for morphologically related words. Journal of Verbal Learning and Verbal Behavior, 18, 399-412.

Taft, M. (1979). Recognition of affixed words and the word frequency effect. Memory and Cognition, 7, 263-272.

Taft, M. (1981). Prefix stripping revisited. Journal of Verbal Learning and Verbal Behavior, 20, 289-297.

Taft, M. (1994). Interactive-activation as a framework for understanding morphological processing. Language and Cognitive Processes, 9, 271-294.

Taft, M. (2004). Morphological decomposition and the reverse base frequency effect. The Quarterly Journal of Experimental Psychology, 57A, 745-765.

Taft, M., \& Forster, K. (1975). Lexical storage and retrieval of prefixed words. Journal of Verbal Learning and Verbal Behavior, 14, 638-647.

Taft, M., \& Forster, K. (1976). Lexical storage and retrieval of polymorphemic and polysyllabic words. Journal of Verbal Learning and Verbal Behavior, 15, 607-620.

Taft, M., Hambly, G., \& Kinoshita, S. (1986). Visual and auditory recognition of prefixed words. The
Quarterly Journal of Experimental Psychology, 38, 351-366.

Ullman, M. T. (2001). The declarative/procedural model of lexicon and grammar. Journal of Psycholinguistic Research, 30, 37-69.

Westermann, G. (2000). A constructivist dual-representation model of verb inflection. In Proceedings of the 22nd annual conference of the cognitive science society (pp. 977-982). Hillsdale, NJ: Erlbaum.

Westermann, G. (2005). Taking development seriously: A constructivist neural network model of inflectional morphology. Paper presented at the 5th International Morphology Workshop, Cambridge, UK.

Wiese, R. (1996a). Phonological versus morphological rules: On German Umlaut and Ablaut. Journal of Linguistics, 32, 113-135.

Wiese, R. (1996b). The phonology of German. New York: Oxford University Press.

Zwitserlood, P., Bölte, J., \& Dohmes, P. (2005, June). Morphological relatedness blocks semantic competitionfor-selection in speaking. Paper presented at the Fifth International Morphology Workshop, Cambridge, UK. 